This article was downloaded by: [University of Massachusetts]

On: 21 April 2009

Access details: Access Details: [subscription number 907140504]

Publisher Routledge

Informa Ltd Registered in England and Wales Registered Number: 1072954 Registered office: Mortimer House, 37-41 Mortimer Street, London W1T 3JH, UK

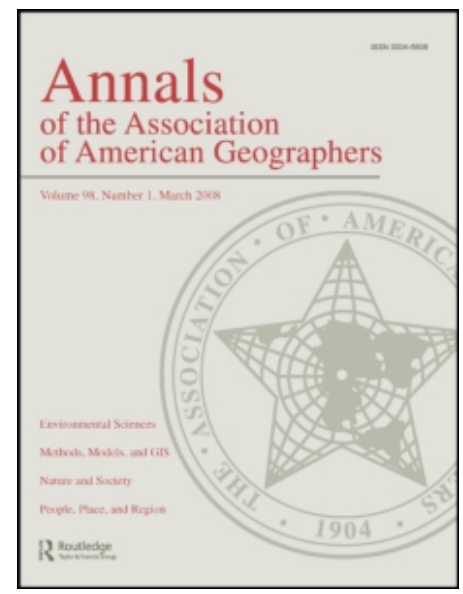

Annals of the Association of American Geographers

Publication details, including instructions for authors and subscription information:

http://www.informaworld.com/smpp/title content=t788352614

\title{
Local Conservation Practice and Global Discourse: A Political Ecology of Sea Turtle Conservation \\ Lisa M. Campbell ${ }^{a}$
}

a Nicholas School of Environment and Earth Sciences, Duke University Marine Lab,

Online Publication Date: 01 June 2007

To cite this Article Campbell, Lisa M.(2007)'Local Conservation Practice and Global Discourse: A Political Ecology of Sea Turtle Conservation',Annals of the Association of American Geographers,97:2,313 - 334

To link to this Article: DOI: $10.1111 /$ j.1467-8306.2007.00538.x

URL: http://dx.doi.org/10.1111/j.1467-8306.2007.00538.x

\section{PLEASE SCROLL DOWN FOR ARTICLE}

Full terms and conditions of use: http://www.informaworld.com/terms-and-conditions-of-access.pdf

This article may be used for research, teaching and private study purposes. Any substantial or systematic reproduction, re-distribution, re-selling, loan or sub-licensing, systematic supply or distribution in any form to anyone is expressly forbidden.

The publisher does not give any warranty express or implied or make any representation that the contents will be complete or accurate or up to date. The accuracy of any instructions, formulae and drug doses should be independently verified with primary sources. The publisher shall not be liable for any loss, actions, claims, proceedings, demand or costs or damages whatsoever or howsoever caused arising directly or indirectly in connection with or arising out of the use of this material. 


\title{
Local Conservation Practice and Global Discourse: A Political Ecology of Sea Turtle Conservation
}

\author{
Lisa M. Campbell \\ Nicholas School of Environment and Earth Sciences, Duke University Marine Lab
}

\begin{abstract}
This article employs political ecology and common property theory to examine sea turtle conservation, how it is articulated and executed at different sociopolitical and geographic scales, and the consequences for local rights of access to resources. It draws on ten years of research at various field sites in Costa Rica, and on sea turtle conservation policy in general, to show that although most sea turtle conservation policy is legitimized in the language of ecology, beliefs about rights to sea turtles as a resource underlie ecological arguments. This becomes clear through analysis of the local, national, and international scales, where ecological arguments are employed differently in order to discount or promote certain types of property rights and to promote particular types of conservation interventions; thus, promoting conservation action at a particular scale is not simply a matter of ecological necessity. The article's main purpose is to outline a political ecology of sea turtle conservation; it also contributes to political ecology and common property theory, and illustrates the productive combination of these for analyzing conservation. Furthermore, it addresses questions about the appropriate scale at which conservation should take place and the rights of local people to use and manage resources, both of which are topics of considerable debate in the wider conservation community. Key Words: common property, Costa Rica, political ecology, scale, sea turtles.
\end{abstract}

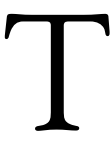
his article employs a political ecology approach to understanding sea turtle conservation, how it is articulated and executed at different sociopolitical and geographic scales, and the consequences for local rights of access to resources. In the broad field of political ecology (see Blaikie 1999; Watts 2000; Walker 2005), the article adopts a critical-realist approach, recognizing that threats to the survival of sea turtles are real but that different accounts of ecology as a representation of biophysical reality exist. In this sense, "'critical' political ecology may be seen to be the politics of ecology as scientific legitimatization of environmental policy" (Forsyth 2003, 4). As will be shown, most sea turtle conservation policy is legitimized in the language of ecology and biology. In particular, many sea turtle biologists and conservationists (hereinafter "experts") cite the global status of sea turtle populations and their long distance migrations as the most important features impacting on their conservation, and which mandate an international or national, rather than a local, approach to conservation. However, underlying arguments about global status and migrations are experts' beliefs about rights (of local people, scientists, tourists, and governments) to sea turtles as a resource. When these experts are active in policymaking at the international and national levels, and in designing conservation projects at the local level, their beliefs translate into material outcomes for local people living with sea turtles. By exam- ining sea turtle conservation at different sociopolitical and geographic scales, and how ecological arguments are employed differently at each to discount or promote certain types of property rights, this article shows how sea turtle ecology can mask the politics of their conservation.

The article brings together ten years of empirical research relating to sea turtle conservation at specific study sites in Costa Rica, Costa Rica's approach to wildlife conservation, and the international sea turtle conservation community and its policies. This research has examined how general wildlife conservation narratives have been received by the international sea turtle conservation community and at the national level in Costa Rica, and whether these narratives are reflected in locallevel conservation projects. As such, it has explored conservation as both discourse and material practice. Results from individual studies have been published elsewhere; this article brings these results together to outline a political ecology of sea turtle conservation that pays detailed attention to the local, national, and international scales, and to interactions between these. ${ }^{1}$

This article responds to Brown and Purcell's (2005) call for more attention by political ecology to the "politics of scale." It shows that promoting conservation action at a particular scale is not simply a matter of biological or ecological necessity, but serves the political interests of particular groups. By drawing on common 
property theory to assess property rights assignments, the article also responds to critiques by both Young (2001) and Giordano (2003) regarding the failure of geographers to engage with this literature. Therefore, in addition to the main purpose of outlining a political ecology of sea turtle conservation, this article also contributes to political ecology and common property theory and illustrates their productive combination for analyzing conservation. Furthermore, although sea turtles are the focal species in this article, questions about the appropriate scale at which conservation should take place, and the rights of local people to use and manage resources, are topics of considerable debate in the wider conservation community. Such debate is epitomized by current promotion of (e.g., Hulme and Murphree 2001; Brechin et al. 2002) and backlash against (e.g., Oates 1999; Terborgh 1999, 2000) community-based conservation, which can be understood as part of a larger debate between "pro-parks" and "pro-people" camps in conservation (Brockington, Igoe, and Schmidt-Soltau 2006; Redford, Robinson, and Adams 2006). Results of this analysis may contribute to, or at least further our understanding of, these debates.

The article is divided into three main parts. The first part provides the necessary background for the analysis and has three sections. The first section explores the utility of political ecology and common property theory for furthering our understanding of conservation policy and outcomes. The second section discusses key elements of sea turtle biology and ecology, particularly the global status of sea turtle populations and their longdistance migrations. The third section describes traditional approaches to conserving sea turtles, draws on original research with sea turtle experts to evaluate their responses to contemporary wildlife conservation narratives, and describes an epistemic community that controls the way in which sea turtle conservation is conceived of and articulated through such narratives. These three sections provide a context for understanding the second part of the article, where examples of how sea turtle biology and ecology are used to inform the assignment of property rights at different sociopolitical scales are described. The examples from the local and national levels draw on case study research conducted in Costa Rica, and the international example is the InterAmerican Convention for the Conservation of Sea Turtles (IAC), to which Costa Rica is signatory. Following the presentation of the local, national, and international examples, the ways that the different scales interact to mutually reinforce or contradict each other are discussed. The final part of the article summarizes implications of the analysis for political ecology, common property theory, and contemporary debates about conservation in general.

\section{Background}

\section{Combining Political Ecology and Common Property Theory}

Zimmerer and Bassett (2003) suggest that geographers interested in political ecology have often studied protected areas due to their spatial definition and the way this allows for direct control over access to resources. However, migratory species and efforts to conserve them are equally ripe for treatment by geographers because these species defy spatial boundaries and move across social and political scales. Five of the seven species of sea turtle are found globally at midlatitudes, and some species range even further (e.g., leatherbacks; see Gulko and Eckert 2004). From this perspective, sea turtles are particularly interesting due to their global distributions and their status as charismatic mega-fauna whose plight is known to the public. ${ }^{2}$ The public appeal and global distribution of sea turtles results in a sea turtle conservation community-composed of scientists, policymakers, volunteers, and lobbyists-that is large and diverse, geographically and socioeconomically. There is also a North-South dimension with, for example, wellfunded researchers based primarily in the United States and Europe studying sea turtle genetics and migrations with sophisticated and expensive technologies (e.g., DNA analysis and satellite telemetry), while many conservationists working in remote areas of the developing world struggle to fund basic monitoring. Sea turtles enjoy high levels of protection in most developed countries but are consumed (both legally and illegally) in many parts of the developing world. The Marine Turtle Specialist Group (MTSG) of the World Conservation Union (IUCN) is arguably the most powerful international player in sea turtle conservation and, although the group has global membership, representation from the North has historically exceeded that from the South. ${ }^{3}$ Thus, there are potentially conflicting views of how sea turtles should be managed and considerable power differentials between actors (for discussion of the NorthSouth dimensions of international conservation, see McCormick 1989; Neumann 1998; Adams 2001). As a result, several interests of political ecologists are relevant. For example, Stonich's (1998) essential elements of political ecology include analysis of the ideologies that direct conservation and influence which social actors benefit and which are disadvantaged, international interests that promote particular patterns of natural 
resource use, and the role of the state in determining and implementing policies that favor the interests of certain actors over those of others. These elements resonate throughout the examples presented in the second part of the article.

The global distribution of sea turtles and the NorthSouth dimension of their conservation also invoke issues of scale. Political ecology claims an interest in scale; however Brown and Purcell (2005) argue that political ecologists have failed to consider scale as an "object of inquiry" and instead treat the local, national, and international as ontologically given. They suggest that scale should rather be treated as political, and specifically as socially constructed, both fluid and fixed, and a relational idea. Rather than using scale to determine the level of analysis, political ecologists should examine the politics of scale as part of the research agenda. Brown and Purcell (2005) also identify the interplay of the political scale with ecological scale as an area of future research. By examining sea turtle conservation at different sociopolitical and geographic scales, and how ecological arguments are employed differently at each, this article responds to both the critique of current treatment of scale and the call to integrate the analysis of political and ecological scale.

Like many wildlife species, sea turtles are most often treated as common pool resources. Young (2001) and Giordano (2003) suggest that geographers have been relatively disengaged from the commons argument, in spite of its relevance to many aspects of geographical inquiry. Giordano points to the basic underlying principles of scale and space: "The commons problem is, in the simplest terms, a general resource problem with particular spatial characteristics related to resource domains and rights assignment" $(2003,367)$ and "the problem for any given resource must be defined for a particular sociopolitical scale if its nature is to be fully articulated" (369). Giordano develops a scale and space-explicit theory of the commons to address this gap in the geographic literature. He takes sociopolitical scale as fixed in a way that Brown and Purcell (2005) would disapprove of; nevertheless his analysis does highlight the importance of different scales when management options for migratory species are considered.

To explain his theory of scale, Giordano (2003) uses the example of an international treaty that articulates how rights are assigned to signatory countries, but not how rights are assigned within each country. Giordano raises the issue of space to highlight how property rights assignments (and the tendency to overexploit resources in a tragedy of the commons scenario) will be impacted by the spatial distribution of a resource and whether it is private, open access, fugitive, or migratory (Figure 1). Scenario D in Figure 1 is most appropriate for sea turtles, but, as will be shown, Giordano's diagram requires expansion to account for the long-distance migrations that sea turtles make across space and scale.

Critical to the analysis presented in this article is the concept of property rights and how these are interpreted and assigned to local people by conservationists. Agrawal and Ostrom (2001) outline four categories of property rights related to common property regimes: (1) withdrawal rights are characterized by the right to enter a defined physical area and obtain resource units or products of a resource system; (2) management rights allow the holders to regulate internal use patterns and transform the resource by making improvements; (3) exclusion rights refer to the right to determine who will have withdrawal rights and how those rights may be transferred; and (4) alienation rights are characterized by the right to sell or lease withdrawal, management, and exclusion rights. There are few cases of sea turtle conservation involving states surrendering alienation rights, and only rights of withdrawal, management, and exclusion are discussed in the remainder of the article. Political ecologists have long been interested in the rights of local people, but few distinguish between different types of rights. Thus, common property theory provides a framework for a more nuanced analysis of rights.

Young $(2001,284)$ highlights the role of the state in defining local access rights to common pool resources, and argues that changes to these can be understood as part of "a dynamic process of changing state-society relations." States remain the arbiters of rights to sea turtles when they are present within national territories, but migrations also take sea turtles through international waters where conservation measures, when they exist, are international. Sea turtle biologists and conservationists are powerful actors in assigning rights in both national and international conservation. Power over how resources are conceived of and managed is a central concern of political ecologists (Bryant 1998), and the combination of political ecology (differentiating between types of power), common property theory (differentiating between types of property rights), and attention to scale and space (both sociopolitical and geographic) provides an analytical framework for examining conservation policy and practice.

\section{Sea Turtle Ecology: Status and Migrations}

Among the number of biological and life history characteristics of sea turtles that complicate efforts to manage them, the status of sea turtle populations and 
A
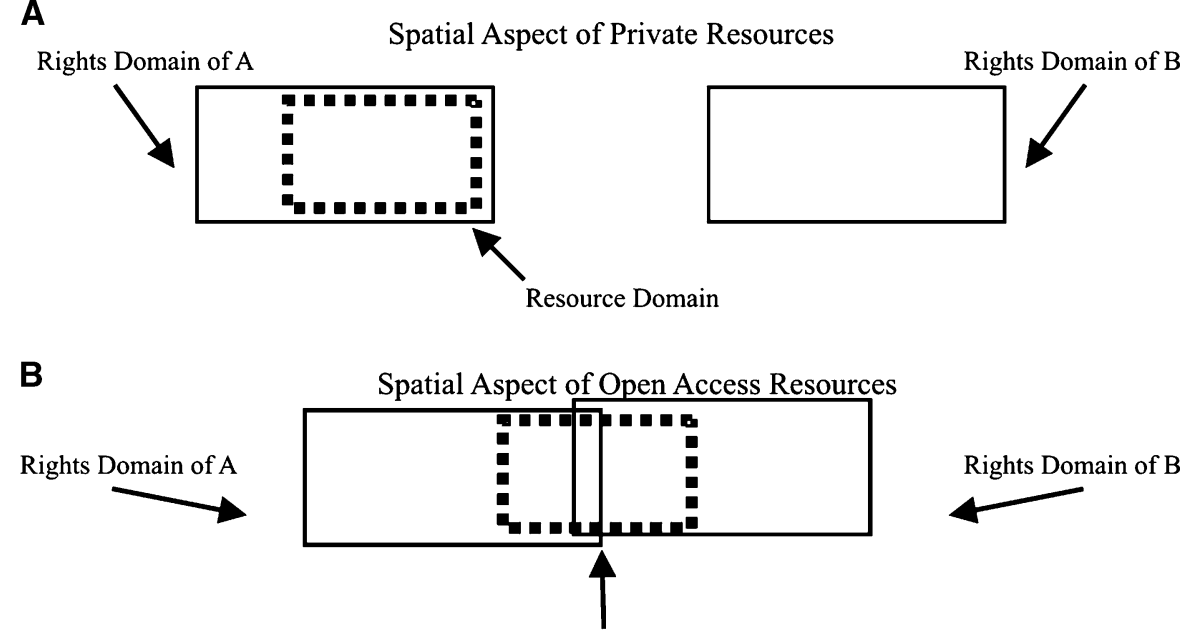

Resource Domain
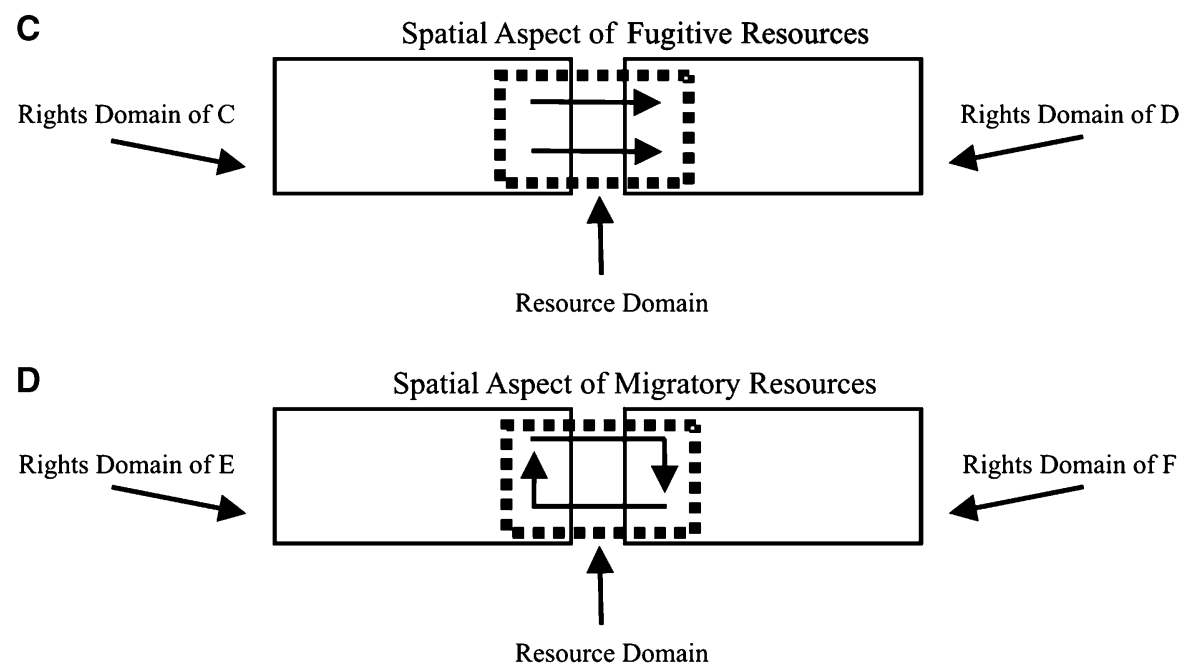

Rights Domain of B

Figure 1. Spatial aspects of (A) private, (B) open access, (C) fugitive, and (D) migratory resources (Giordano 2003, 370). their long distance migrations emerge as key features impacting on conservation (Campbell 1997, 2002c). These are discussed in detail below.

Regarding population status, there are seven species of sea turtles: flatback (Natator depressus), green (Chelonia mydas), hawksbill (Eretmochelys imbricata), Kemp's ridley (Lepidochelys kempii), leatherback (Dermochelys coriacea), loggerhead (Caretta caretta), and olive ridley (Lepidochelys olivacea). There are no definitive population estimates for any species, however the IUCN's Red List categorizes leatherbacks, hawksbills, and Kemp's ridleys as critically endangered; greens, loggerheads, and olive ridleys as endangered; and flatbacks as data deficient (http://www.redlist.org/).

The MTSG is the organization responsible for advising on the Red List, and the process has been controversial for the group (Mrosovsky 1997, 2003) for several reasons. First, Red List endangerment criteria are prob- lematic for sea turtles. Endangerment is calculated based on declines in populations over three generations, but because sea turtles are long-lived, declines (or increases) are estimated using existing nesting beach data (with few data sets covering more than two decades) and projecting trends backward in time, up to $200+$ years ago. Whether these projections adequately reflect reality is unknowable, and projections vary depending on whether a linear or exponential function is applied (see Seminoff 2004a). Second, nesting numbers are used as an indicator of overall population size. However, the link between number of nesting females, adult males, and juvenile turtles is unknown (Pritchard 1997b; Gerrodette and Taylor 1999). Third, although the Red List assesses threats to global populations, there is considerable regional variation in aggregations.

Two examples of regional variation are relevant to the examples discussed in this article. First, leatherback 
turtles are believed to have declined dramatically in the Pacific Ocean (Spotila et al. 2000), but there is evidence of increases in the Atlantic (Boulon, Dutton, and McDonald 1996; Hasting 2003; Dutton et al. 2005; Stewart and Johnson 2006). Second, according to the 2004 Red List assessment for green turtles, the species is globally endangered (Seminoff 2004a). However, nesting populations in the western Atlantic and Caribbean have increased 13-66 percent (depending on a linear or exponential projection) and an estimated 31,000 adult females nest each year (Seminoff 2004a). Seminoff (2004b) suggests that if turtles were listed regionally, this population would not meet the criteria for an endangered listing. Due to dissatisfaction with the Red List process, Seminoff (2004b) and Mrosovsky (2003, 2004) have encouraged the MTSG to move to regional rather than global listings. Such a move would likely encounter resistance, however, as global status is often invoked to justify particular forms of conservation (and the scale at which it occurs), even when regional populations are believed to be increasing (see the second part of this article).

Regarding migrations, sea turtles are highly migratory over life spans that can last several decades. The life cycle begins when hatchling turtles emerge from their nests on beaches and crawl to the ocean. Once in the water, hatchlings begin a "swimming frenzy" to reach offshore waters, a two- to three-day effort (Salmon and Wyneken 1994). After this initial activity, migrations and use of habitat across age groups of different species are largely unknown. For example, hatchlings enter a stage that has been called the lost year (Carr 1981). One theory is that turtles spend this time being passively transported in warm ocean currents (Bolten 2003), but data are lacking for all species and populations. After an unknown period, juvenile turtles emerge from this pelagic stage and move through a series of developmental habitats, often spending several years in each. Studies of juvenile turtles and their use of habitat are being undertaken (Bolten et al. 1998; Avens et al. 2003; James, Ottensmeyer, and Myers 2005), but most focus on loggerhead turtles in the northern Atlantic, and their applicability to other species and loggerhead populations is unknown. As adults, turtles migrate between foraging grounds and nesting beaches, sometimes covering thousands of kilometers (Hughes et al. 1998; Ferraroli et al. 2004).

As in other fields of conservation (see Zimmerer 2006), technology has impacted on sea turtle conservation, and satellite tracking and genetic identification of sea turtles have specifically influenced the study of migrations; genetic analyses can identify the nesting and breeding grounds for particular haplotypes of turtles (Bowen and Karl 1996), and satellite telemetry provides a direct illustration of migratory patterns (Luschi et al. 1998; Ferraroli et al. 2004). Due to the expense of satellite tracking technology, small sample sizes limit the contributions of many studies (Chaloupka, Parker, and Balazs 2004). Nevertheless, technological advances and their potential to increase understanding of sea turtle migrations and population structures have made DNA analysis and satellite telemetry popular topics for researchers, and have focused attention on the implications of migrations for conservation.

\section{Approaches to Sea Turtle Conservation}

Sea turtles face a variety of threats, including their direct consumption at all life stages by humans and other predators, incidental capture (and often death) in fishing gear, loss of nesting habitat through coastal development, and degradation of in-water habitat through pollution (for a review of human induced threats, see Lutcavage et al. 1997). Threats vary geographically; for example, direct take is not very important in the United States, but coastal development is. The overall impact of threats on populations is unknown due to lack of information on population numbers, structure, and dynamics, and this makes designing effective sea turtle conservation policy challenging.

In spite of these challenges, in the past fourteen years the MTSG has produced an Action Plan (Bolten and Bjorndal 1993), a Global Strategy for the Conservation of Marine Turtles (MTSG 1995), and a manual of Research and Management Techniques for the Conservation of Sea Turtles (Eckert et al. 1999). A full review of these documents is beyond the scope of this article. Rather, the MTSG's positions on two contemporary themes in wildlife conservation, sustainable use and communitybased conservation, are considered. As these concepts address use of and control over resources, they are linked to the question of rights to resources. Furthermore, community-based conservation is specifically implicated in the question of the appropriate scale for conservation, since it preferences the local. Therefore, part of the project of revealing the political ecology of sea turtle conservation involves understanding how these concepts are received (or not) by the sea turtle conservation community.

Following Roe's (1991) analysis of development narratives, sustainable use and community-based conservation can be understood as components of a conservation counternarrative, one that has arisen over the past thirty years in opposition to a traditional con- 
servation narrative. Inherent in these narratives are assumptions about the appropriate scale at which conservation should take place and the rights of various actors to protected resources. The traditional narrative describes wildlife populations as threatened directly with extinction by local harvesting and indirectly by habitat degradation and fragmentation. Local people are identified as the problem, and the solution is to remove wildlife to protected areas, where it is not subject to exploitation or competition. This protection is enforced by the state, and if local people continue to hunt or harvest they are labeled poachers and thereby reconfirm beliefs about the source of the problem. As they are breaking the law, the solution becomes more and better enforcement (Campbell 2000).

This traditional narrative retains its hold on many conservation organizations, but in developing countries its appropriateness has been questioned due to the failure of national parks (Adams and Hulme 2001). ${ }^{4}$ The promotion of sustainable use is in part to address this failure and is based on the perceived need to imbue wildlife with economic value. By allowing people to use wildlife resources, sustainable use attempts to ensure that wildlife conservation can compete with other habitat uses (Freese 1997, 1998). The discussion of sustainable use distinguishes between consumptive and nonconsumptive use, with consumptive referring to the direct removal of a species or its parts, and nonconsumptive referring to uses like ecotourism that do not result in direct removal (Freese 1998). Some analysts have objected to categorizing ecotourism as nonconsumptive (e.g., Tremblay 2001). This article adopts the term "nonconsumptive use" for ecotourism since this is how most conservationists define it. One of the primary assumptions of sustainable use is that, particularly in developing countries, economic benefits are key to gaining support for conservation. However, this assumption has sometimes proven false. Economic benefits may exist, but if users do not perceive them as significant then local support for conservation may still be lacking. Control over local resources by local people is often equally, if not more, important to gaining support for conservation activities (e.g., Parry and Campbell 1992; Heinen 1993; Campbell 1998). Promoters of community-based conservation argue that participation in and control of use regimes by local people can enhance economic and social security, and can help convince people with marginal livelihoods that it is in their interest to sustain their wildlife resources into the future (Western and Wright 1994). In the language of property rights, withdrawal rights are not the only rights at stake in conservation.
Although both sustainable use and community-based conservation have been criticized, they are powerful components of a conservation counternarrative (Adams and Hulme 2001; Campbell 2002b). For example, the roots of sustainable use can be found in the World Conservation Strategy (IUCN 1980), and the IUCN now has a Sustainable Use Initiative and more than a dozen regional sustainable use specialist groups. Communitybased conservation is perhaps even more ubiquitous, and it would be difficult to find a wildlife conservation project that does not attempt or at least claim to involve the community (Wells and Brandon 1993; Hackel 1999; Lundy 1999; Campbell and Vainio-Mattila 2003).

Consumptive use has been a controversial issue for the MTSG almost since its formation in the 1960s, and although the MTSG does not have an official position on use, evidence of anti-use sentiment exists (Campbell 2002c). More recently, many sea turtle conservationists have embraced the idea of nonconsumptive use through ecotourism, as noted by Godfrey and Drif (2001) and reflected in Troëng and Drews (2004), and the MTSG has adopted some of the language of community-based conservation (e.g., Frazier 1999). Ecotourism is a convenient alternative for conservationists, as promoting "community-based ecotourism" allows them to speak the language of the conservation counternarrative while using the tools of the traditional narrative-that is, protected areas to which ecotourism is often based (Campbell 2002a). This preference for ecotourism resonates in the examples discussed in the second part of the article.

Interviews conducted with forty-two experts in sea turtle biology and/or conservation reveal much about their positions on sustainable use and community-based conservation, and results presented below summarize these positions. ${ }^{5}$ Although the views expressed by these experts are not meant to represent those of all sea turtle experts, it should be noted that approximately 70 percent of interviewed experts hold or held influential positions in policymaking bodies like the MTSG, and 30 percent have direct experience in the Costa Rican examples discussed in the second part of the article. Overall, they form part of an epistemic community that has power over narratives about sea turtle conservation and often over the material practices of local people at specific field sites.

Almost all interviewed experts accepted sustainable use as a valid conservation tool (Campbell 2000), however, most saw sea turtles as an "exception" due to constraints imposed by population status and life history characteristics, including migrations (Campbell 2002c). Status was deemed problematic either because 
Figure 2. Giordano's (2003) "spatial aspect of resources" applied to highly migratory resources.

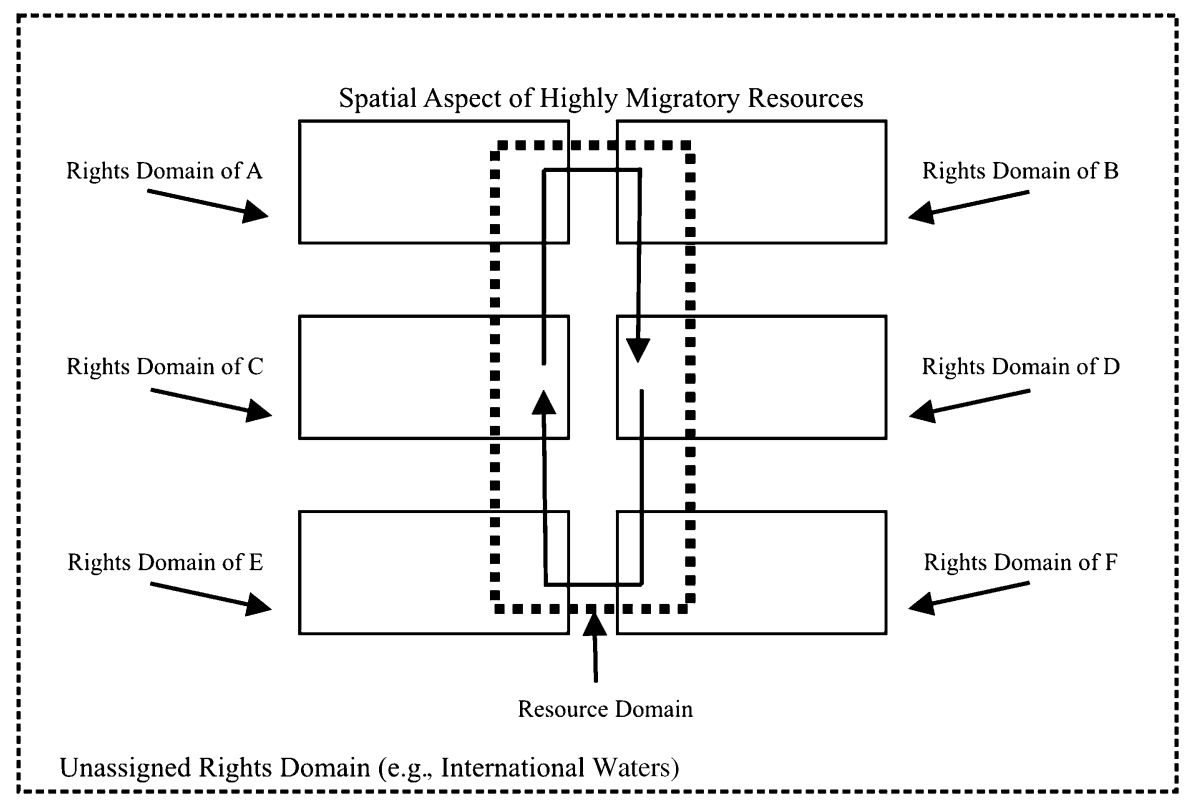

populations were declining or because information on status was incomplete. Migrations were problematic because "(i) all threats along the migratory route may not be known and thus the cumulative impacts on turtles may be underestimated or even ignored; (ii) the migration itself makes it difficult to determine the magnitude of individual and cumulative threats; and (iii) national user groups, types of use, management techniques and objectives along the route may be conflicting" (Campbell 2002c, 1236). Overall, Giordano's (2003) diagram (Figure 1), showing interactions between only two resource domains and lacking unassigned domains (e.g., international waters), is too simple for sea turtles. Multiple rights domains and the explicit recognition of unassigned domains are needed to capture sea turtle distribution and migrations (Figure 2).

Experts highlighted lack of information and uncertainty in discussing constraints on using sea turtles, even those few experts who were not opposed to use (Campbell 2002c). This emphasis on uncertainty is important, as it allows for wide interpretation of the implications of status and migrations for conservation policy; for example, many interviewed experts invoked the precautionary principle to explain their no-use positions. For a detailed analysis of the way uncertainty influences expert positions on the possibilities for using sea turtles as part of a conservation strategy, see Campbell (2002c). Furthermore, experts were more willing to contemplate using marine turtle eggs as opposed to adults, as eggs were seen to be less valuable to populations. Most experts accepted egg harvesting as biologically possible, but few saw it as a legitimate conservation strategy (Campbell 2002c). The local and national examples discussed in the second part of the article involve both egg and adult harvesting.

In contrast to their views on consumptive use, interviewed experts were enthusiastic about nonconsumptive use via ecotourism. They saw it as particularly relevant in developing countries, where it can reduce demand for consumptive use or provide replacement income when consumptive use is eliminated. This enthusiasm existed in spite of expert awareness of the problems with ecotourism in practice. Even experts with most experience with ecotourism, and who were concerned about its environmental impacts on turtles and their habitats, expressed a strong preference for ecotourism over other forms of use (Campbell 2002a). This preference becomes pronounced in the second half of the article.

Experts were asked about local rights to resources and local participation in conservation, and their responses are relevant for understanding the role of property rights in debates about sea turtle conservation. Experts did not distinguish between different types of rights, however, their views have been categorized here in terms of Agrawal and Ostrom's (2001) typology (shown in parentheses). The idea that local people have rights to resources was problematic for most experts, such that many refused to address the issue (in the words of one expert, "I'm not touching that one"). Of those who did address the issue, few believed local people have rights to use resources (withdrawal rights), and most had reservations about the concept of rights in general. They were concerned, first, with nonuniversality of the concept, and how a notion of rights can "slip out of your grasp." Second, rights can interfere with end objectives (i.e., implementing a desired conservation regime), and experts argued for caution in 
assigning rights, lest they be used to override other arguments. Third, local rights (of withdrawal and management) were deemed null and void for globally valued resources, for which "everybody on the planet has a stake" (for further details, see Campbell 2000).

It is in this third argument that the migratory nature of sea turtles and the related issue of scale resurfaces. Interviewed experts invoked sea turtle migrations to discount local rights (of both withdrawal and management), and migrations were simultaneously used to support intervention by outsiders and to assign them rights of both management and exclusion. Some experts struggled with the role of one country interfering with the sovereignty of another, but others dismissed sovereignty issues in the case of sea turtles due to their global value. At the extreme, one expert argued that tourists will pay to see sea turtles nesting on beaches in the tropics, and that these people have equal and even greater rights ${ }^{6}$ than local people (Campbell 2000). Thus, it is not that experts would never assign rights, but they were often hesitant to assign them to local people.

Experts found participation by local people in conservation to be less contentious. However, the concept of community-based conservation often includes caveats relating to community ownership of and control over resources and their management (i.e., rights of management, exclusion, and sometimes alienation), and the experts' views on participation fell well short of this type of empowerment. Many experts talked about the need to work with local people and referred specifically to employing people as conservation officers, educating them about the need to conserve, keeping them informed, and listening to what they had to say. A few experts gave local people a larger role, according them status as coparticipants with resource managers and scientists, but most were adamant that participation should not be used to guide decision-making. Overall, participation was seen as a means to get people on-side with predetermined conservation objectives (Campbell 2000), a vision that falls in the "least participatory" category of the various forms community-based conservation can take (see Pretty 1995; Barrow and Murphree 2001). Given this view of participation, it is not surprising that experts failed to interpret participation in terms of property rights.

\section{Community-Based Conservation and Sustainable Use: Local, National, and International Examples}

Expert views on sustainable use and communitybased conservation provide a context for understanding the local, national, and international examples discussed in this part of the article. The local example is a legalized commercial harvest of olive ridley sea turtle eggs in the Ostional Wildlife Refuge in Costa Rica. Ostional is one of the only documented cases of a commercial, consumptive use of sea turtles that appears to fulfill the objectives of both sustainable use and community-based conservation (Campbell 1998). ${ }^{7}$ The national example is Costa Rica, and the country's approach to conservation is detailed by looking at three other locations (Tortuguero National Park, Gandoca-Manzanillo Wildlife Refuge, and the Caribbean port city of Limón $)^{8}$ where, in contrast to Ostional, consumptive use of sea turtles has been eliminated in the past ten years. The international example is a treaty, the Inter-American Convention for the Protection and Conservation of Sea Turtles (IAC), which identifies eliminating use as a key measure for achieving the convention's objectives. ${ }^{9}$ Costa Rica is signatory to the IAC and houses the current secretariat. In all of the examples, discussion considers how rights to resources are conceived of and allocated, and the role of sea turtle status and migrations in justifying such allocations. Following description of the local, national, and international examples, the interaction between these scales is examined. The point here is not to evaluate the impacts of each example, nor to argue that the local example can or should be replicated elsewhere. Rather, of interest is the way in which the local example contrasts with the national and international, and how this contrast helps to reveal a political ecology of sea turtle conservation.

\section{Local Level: Olive Ridley Egg Harvesting in Ostional}

In the Ostional Wildlife Refuge on the Pacific coast of Costa Rica, olive ridley sea turtles nest in what are known as arribadas, mass nesting phenomena in which hundreds of thousands of turtles emerge over several days on a small stretch of beach to lay their eggs. This happens approximately once a month, throughout the year. The number of turtles nesting varies, but during the wet season when nesting is highest an estimated 20,000 130,000 turtles nest in each arribada (Chaves 2002). There is a legalized commercial harvest of turtle eggs by residents of Ostional Village, run by a community cooperative (Campbell 1998). On average, approximately 17 percent of eggs laid are collected during arribadas (Ballestero, Arauz, and Rojas 2000). From a biological perspective, the harvest is believed to be sustainable (Cornelius et al. 1991). After an estimated thirty years of uncontrolled exploitation and a further twenty years of legal exploitation, existing data suggest no overall de- 
crease in nesting numbers (Ballestero, Arauz, and Rojas 2000). ${ }^{10}$ The cooperative also undertakes turtle protection efforts, like beach guarding and cleaning (Campbell 1998). In terms of socioeconomic sustainability, there is substantial support for the project throughout the community, primarily because of the significant monetary benefits derived from it. Other elements complement these benefits and enhance support for the project, including the legal and administrative frameworks that support the project and the high level of community participation in its management. It is the combination of these factors-substantial and secure economic benefits and community control-that encourages reinvestment of profits into community development, promotes an equitable approach to profit distribution, and encourages respect for rules. Individual and collective stakes in the project are high enough to discourage illegal harvesting and to encourage community self-policing (Campbell 1998).

The rights of the cooperative and its members were established in the original laws allowing the harvest (see Campbell 1998, 310). In terms of withdrawal rights, there are restrictions. Spatially, the harvest is limited to an 800-meter stretch of beach where the majority of arribada nesting occurs. Sporadically, the arribada shifts to a different section of the beach, as does the harvesting; and although a spatial shift in the harvest is not officially sanctioned, it is tolerated. The community's withdrawal rights are also restricted temporally to the first thirty-six hours of an arribada. At all other times, collecting sea turtle eggs is prohibited.

Management rights are stipulated in the original law allowing for the harvest. The community is responsible for almost all aspects of project management, and these responsibilities are exercised through an elected Junta (board of directors). The Junta organizes work groups and additional turtle protection activities (e.g., beach guarding and cleaning), pays for environmental monitoring, sets and administers fines, pays salaries, awards contracts for egg selling routes, and invests profits in community development projects. The Junta cannot change the temporal nature of withdrawal rights, but within the thirty-six-hour period it can decide how much or little to harvest. Punishment for individual members caught breaking the rules is determined by the Junta and is usually a ban from one or more future harvests (Campbell 1998).

The cooperative exercises exclusion rights. Participation in the cooperative was originally restricted to residents of Ostional who had been there for at least five years and who were over the age of fifteen. Ostional was defined to include outlying farms and households located along the road for several kilometers in either direction. No formal record of how these limits were defined was found in project documents, but according to local informants the boundaries were determined based on how these households were traditionally identified (Campbell 1997). Children of members could become members themselves on turning fifteen and, originally, immigrants could join once they had resided for five years and paid a membership fee. New membership is now open only to children of existing members. Membership restrictions were part of the original management plan (a ceiling of 150 members was set, but this has been exceeded). Recognition of the need to limit membership (and egg harvesting) is offset to some extent by sympathy for expanded membership and concern for issues of fairness (Campbell 1998). Because the temporal restrictions on the harvest ultimately limit how many eggs can be taken, increased membership is more likely to lead to decreased profits per member than to a greater numbers of eggs harvested.

Support for the project among Costa Rican residents in Ostional who are not members of the cooperative is high, as most of these people provide goods and services in town and recognize that the egg harvest provides money for such purchases (Campbell 1998). However, residents of surrounding villages lost open access to eggs when the project was established. To compensate for this loss, outside families are allowed to collect one-hundred eggs per household for personal consumption immediately following the formal collection (Campbell 1998).

The Influence of Sea Turtle Status and Migrations on Rights at Ostional. Olive ridleys are believed to be the most numerous sea turtle species (Pritchard 1997a). They are listed as endangered on the IUCN Red List, which is probably suitable for Atlantic Ocean populations, but the situation in the Pacific basin is different. The end in 1990 of a large commercial harvest of olive ridleys in Mexico and a subsequent (and surprisingly rapid) rebound in nesting numbers at key beaches (Márquez, Peñaflores, and Vasconcelos 1996) have contributed to population stability and a likely increase. Thus, the overall status of olive ridleys cannot be used to argue against the Ostional egg harvest by those who oppose consumptive use.

Perhaps because olive ridleys are more numerous than other species, there have been few studies of olive ridley migrations (but see Plotkin et al. 1995). Some regional migration is likely, however, and movement between Ostional Beach and a second arribada aggregation to the north, at Nancite Beach in Santa Rosa National Park, has been observed (H. Kalb, unpublished data). ${ }^{11}$ Far 
from human settlement, the beach at Nancite is not subject to human exploitation. Olive ridleys also nest solitarily at a number of locations along the Pacific Coast of Costa Rica (and in many countries of the region). Eggs from some nests on these beaches are harvested illegally, but in general exploitation elsewhere is not invoked as an argument against Ostional. In fact, one of the original goals of the project was to saturate the national market with legal eggs from Ostional, which, when combined with price controls, would discourage illegal harvesting elsewhere (Campbell 1998). The intended spatial impact was conceived as both local and national; however, there have been few studies evaluating the success of this objective.

It is also difficult to invoke migrations as an argument against egg harvest versus turtle harvest. Turtles move through space and across scale; eggs are deposited at local beaches. Eggs result in hatchlings that do migrate and become part of a shared population, but sea turtle experts are generally more tolerant of egg harvesting, due to low survival rates of hatchlings to adulthood (an estimated one in 1,000 hatchlings reaches maturity). There is specifically tolerance for egg harvesting on arribada beaches (Campbell 2002c), where the mass arrival of thousands of turtles to a small stretch of beach over several days means that eggs laid early in the arribada are often dug up and destroyed by subsequent nesting females. This is, in essence, the biological rationale for the harvest: eggs collected during the first thirty-six hours would likely be destroyed if not collected.

\section{National Level: Turtle-Based Tourism in Costa Rica}

The Ostional egg harvest is an exception to the rule of sea turtle conservation in Costa Rica. To provide a sense of this national approach, property rights, and how the discussion of these is impacted by sea turtle status and migrations, are considered at three other sea turtle sites in Costa Rica, all on the Caribbean coast. Tortuguero National Park protects what is considered the largest rookery for green turtles in the Atlantic (Troëng and Rankin 2005). An estimated 27,000 females nest annually, and Tortuguero is one of the region's beaches that has seen increased nesting over three generations (of 93-100 percent; Seminoff 2004a). A U.S.-based nongovernment organization (NGO), the Caribbean Conservation Corporation (CCC), has a permanent field station there and has maintained a green turtle tagging program since the 1950s. It runs a volunteer program to support its work financially and with labor (Campbell and Smith 2005, 2006).
The port city of Limón and capital of Limón Province was the center of a regional green turtle fishery that thrived until the 1960s and continued at low levels until 1999. This fishery drew on the Western Atlantic and Caribbean green turtle population that is believed to be increasing (Seminoff 2004a). The CCC has increasingly played a role in turtle conservation in Limón, through its national office in San José.

The Gandoca-Manzanillo Wildlife Refuge includes a leatherback nesting beach adjacent to Gandoca Village. Nesting is believed to be increasing, and Chaverri (1999) argues that Gandoca is the second most important rookery for leatherbacks in the Caribbean. A national NGO named ANAI runs a turtle conservation project in Gandoca, through locally employed staff and international volunteers (Gray 2003). The harvest of sea turtles and their eggs is prohibited throughout Costa Rica, and has been since 1966 under Wildlife Conservation Law 4551 (the 1983 Wildlife Conservation Law 6919 allows for the Ostional egg harvest as an exception). However, limited consumptive use was authorized, or tolerated, until very recently in all three of these examples.

Tortuguero residents participated in the regional green turtle fishery during the first half of the twentieth century, and green turtles were taken from the beach until the Park was established in 1975 (Parsons 1962; Lefever 1992). After the Park's establishment, Tortuguero residents retained limited withdrawal rights. These allowed a harvest of a few green turtles per week (estimates vary from one to three), to share among community members in order to meet cultural demand for turtle products. By the mid-1990s, this use had been curtailed, first by rules changes that were onerous to the extent that the community no longer applied for this right (Campbell 2002a), and more recently by stronger sea turtle protection laws. ${ }^{12}$ There is evidence that some local people, particularly long-term residents, would like access to a limited number of turtles for consumption (Peskin 2002). For example, a group of local people proposed that they be allowed to take turtles found freshly dead on the beach (specifically those killed by jaguars and missing only the head and flippers). Park employees denied this request because it was not in line with Costa Rica's strict nonextractive policy (personal communication, Zoë Meletis, PhD researcher, Duke University, October 2004).

The regional green turtle fishery based out of the city of Limón served international markets for turtle products, primarily in the United States and Europe (Parsons 1962). Following the outlawing of turtle fishing in Costa Rica (and, perhaps more important, the closure of many foreign markets), the commercial fishery eventually 
stopped. However, to meet cultural demand for turtle meat, a 1983 law reinstated some withdrawal rights for Limón fishers by licensing an annual catch of 1,800 green turtles. In 1999, this fishery was closed following a petition by Costa Rican and U.S. NGOs, including the CCC. The arguments for closure were based on the constitutional legitimacy of the law allowing the harvest, Costa Rica's commitments to international agreements, and failure to adequately enforce the law (Taft 1999).

Leatherback turtle eggs were collected by residents of Gandoca Village for subsistence purposes until the Gandoca-Manzanillo Wildlife Refuge was established in 1985 and ANAI began a turtle project on Gandoca Beach. Unrestricted access to eggs then halted, though limited withdrawal rights were retained by villagers until the mid-1990s. Local families were given the right to harvest a certain number of eggs, and this number was negotiated annually by Refuge staff, ANAI, and the community. Thus, the community theoretically shared in management rights. The rationale for the harvest was described by ANAI as follows:

Information collected from Gandoca residents shows that community support for the project will increase, and poaching by locals will be reduced if local residents are permitted to consume moderate numbers of eggs in a controlled manner. In many cases it appears that what matters is not so much whether a given family obtains eggs as that they do not feel prohibited from doing so.

-(ANAI 1995)

At that time ANAI recognized the political importance of maintaining withdrawal rights, however, the limited egg collection no longer occurs. The decision to end the harvest was made by Refuge staff and ANAI, and the community was reportedly divided over the issue (Gray 2003).

With the end of the withdrawal rights at Tortuguero, Limón, and Gandoca, rights of management and exclusion as held by communities become moot. There is evidence that local communities had some say in management decisions about extraction programs (e.g., the community in Gandoca participated in negotiating the annual number of eggs harvested), but those in support of harvesting were eventually overruled by those who were not. The term "community" is itself problematic; for example, in Tortuguero the views of the community have changed dramatically over the past decade as ecotourism has grown, and many residents are fully supportive of the nonconsumptive use policies of the Park (Peskin 2002). Though there is a danger in setting up a dichotomy, with the community in opposition to NGOs and government, it remains true that some community members lost access to resources against their wishes.

In all of these examples, ecotourism is proposed as an alternative use of sea turtles, one that allegedly brings economic benefits to communities and encourages their participation in conservation (Campbell 2002a). Costa Rica's general approach to wildlife conservation is nonconsumptive, with wildlife for use by ecotourists (national and international), the ecotourism industry, and scientists. Ecotourism is a national priority, and Costa Rica has cultivated a green image to capitalize on this growing segment of the travel industry (Campbell 2002b). Tortuguero is a prime destination for ecotourists, receiving in excess of 80,000 tourists in 2004 (Harrison et al. 2005), many of whom visit to see green turtle nesting (Jacobson and Robles 1992; Lee and Snepenger 1992). Gandoca has a much smaller tourism industry, with approximately 300 tourists visiting as volunteers working for ANAI and very few independent visitors (Gray 2003). Limón is targeted for tourism development (Cuevas 2002), but progress has been slow (Troëng, Castro, and Chamorro 2004) and the city receives few visitors relative to its size and to other tourism destinations on the Caribbean coast.

The growth of tourism and its economic importance fuel arguments against traditional withdrawal rights. Tourism and consumptive use of turtles are portrayed as incompatible (Campbell 2002a), particularly by the CCC, whose scientific director in 2004 coauthored a World Wildlife Fund (WWF) study on ecotourism that argues for the incompatibility of consumptive and nonconsumptive use, and the greater economic value of nonconsumptive use (see Troëng and Drews 2004). Tourism restricts more than access to turtles, however; in Tortuguero and Gandoca, it also restricts access to the beach (public space under Costa Rican law) during the nesting season. Park staff and NGO staff and volunteers have access to the turtles and beaches, but all other people are restricted from the beach from 6 p.m. onward, unless accompanied by a guide. In both places, tourists gain access through payment of a fee, and volunteers with the CCC and ANAI gain access through paid registration in their respective volunteer programs.

The Influence of Green and Leatherback Turtle Status and Migrations on Rights in Tortuguero, Limón, and Gandoca. Nesting numbers have traditionally been used as indicators of population status. Given the increasing nesting population of green turtles in Tortuguero specifically and the region in general, restrictive conservation policies for this species cannot be justified based solely on nesting numbers. Instead, the CCC highlights sea 
turtle migrations in its conservation discourse, and the importance and size of the Tortuguero nesting population and the long history of flipper tagging means that there are extensive data on where Tortuguero green turtles go. There are other ways of discounting the importance of nesting increases at Tortuguero. Bjorndal and Bolten (2003) have argued that it is not enough to see nesting numbers increase; the goal for population recovery must be population sizes reported by early explorers to the Americas. Campell and Lagueux's (2005) population modeling also warns of an impending crash in Caribbean green turtle populations, including nesters at Tortuguero, due to harvesting in Nicaragua.

The CCC also satellite tracks turtles, both as an education tool and to further understand migrations. These migrations are invoked in two ways. First, migrations mandate the intervention of the CCC in other places; the CCC was one of the petitioners in the closure of the Limón fishery (Taft 1999), for example, and is now focused on other key migration spots: "tag returns make it clear that turtles nesting there [Tortuguero] disperse to feeding areas throughout the Caribbean. A large portion of them go to the Miskito Coast of Nicaragua. Efforts are now focussed on limiting the number of turtles killed there for meat" (CCC 2003b). Second, migration of Tortuguero's nesting green turtles to places where they remain under threat mandates continued and even increased vigilance at Tortuguero.

Global leatherback status is effectively invoked in discourses about conservation at Gandoca (and in the region), even as leatherback nesting at Gandoca Beach may be increasing. The decline of the Pacific leatherback is currently a hot topic in sea turtle conservation, and has been since a Nature publication (Spotila et al. 2000) that predicted impending extirpation in the absence of drastic action. Leatherbacks were listed as critically endangered on the IUCN Red List in 2000, but, as previously discussed, the situation of Atlantic leatherbacks is quite different, with increased nesting on key beaches throughout the region. Troëng, Chacón, and Dick (2004) conclude that leatherback nesting along the Caribbean coast of Central America represents the fourth largest nesting colony in the world. Nevertheless, the global status of leatherback turtles is invoked as mandating regional conservation efforts: "The decline in global nest numbers means that the leatherback research and conservation efforts on the Caribbean beaches of Central America are becoming increasingly important" (CCC 2003a)..$^{13}$

The migratory nature of leatherbacks and their unique nesting behavior combine with their status in an interesting way. Most sea turtle species show strong fidelity to specific nesting beaches, whereas leatherbacks often nest at multiple beaches in a particular region (Eckert et al. 1989; Girondot and Fretey 1996). Chaverri (1999) and Troëng, Chacón, and Dick (2004) agree that leatherback nesting at Gandoca Beach is increasing, though Troëng, Chacón, and Dick evaluate this trend in terms of a regional population of leatherbacks migrating between nesting sites along Costa Rica's Caribbean coast. They cite negative trends at other beaches (including Tortuguero) to argue for a possible decline in the regional population. ANAI identifies migrations as critical and is beginning to study them in order to contribute to regional and international management by "competent organizations” (Chacón and Hancock 2004). ANAI specifically cites regional migrations between nesting sites as an additional complication for management.

\section{International Level: Eliminating Use through the Inter-American Convention for the Protection and Conservation of Sea Turtles}

The Inter-American Convention for the Protection and Conservation of Sea Turtles (IAC) entered into force on 2 May 2001. ${ }^{14}$ Currently, ten states have ratified the IAC (Belize, Brazil, Costa Rica, Ecuador, Honduras, Mexico, Netherlands, Peru, the United States, and Venezuela), and two are signatories (Nicaragua and Uruguay). The stated purpose of the IAC is "to promote the protection, conservation and recovery of sea turtle populations and of the habitats on which they depend, based on the best available scientific evidence, taking into account the environmental, socio-economic and cultural characteristics of the Parties" (Article II). The first measure listed toward achieving that purpose is "The prohibition of the intentional capture, retention or killing of, and domestic trade in, sea turtles, their eggs, parts or products" (Article IV, 2.a). Thus, the convention delivers a strong message opposed to consumptive use.

The first measure of the IAC makes clear that withdrawal rights to sea turtles are to be curtailed throughout the entire region (at least in the territorial waters and on the beaches of signatory states). There is an exception clause (Article IV, 3.a) related to Article IV, 2.a, which allows for withdrawal rights to be extended under certain circumstances:

Each Party may allow exceptions to Paragraph 2(a) to satisfy economic subsistence needs of traditional communities, taking into account the recommendations of the Consultative Committee established pursuant to Article VII, 
provided that such exceptions do not undermine efforts to achieve the objective of this Convention. In making its recommendations, the Consultative Committee shall consider, inter alia, the status of the sea turtle populations in question, the views of any Party regarding such populations, impacts on such populations on a regional level, and methods used to take the eggs or turtles to cover such needs.

The exception clause reveals much about how rights are conceived in the IAC. It stipulates that some withdrawal rights may be awarded for subsistence use by traditional communities, but neither "subsistence" nor "traditional" is defined, and previous research suggests they are likely to be interpreted narrowly (Campbell 2000). At the second meeting of the IAC's Scientific Committee, the need to define subsistence was identified as a "fundamental" task (IAC 2005, para. 6.c). Furthermore, while it is possible that some communities will retain withdrawal rights under the exception clause, a community's role in securing such rights (i.e., its ability to exercise management or exclusion rights) is not addressed. Rather, the clause allows states to propose exceptions and consider the advice of the IAC's Consultative Committee in doing so. The Committee, in turn, is to consider the view of any Party to the convention and the exception's regional impacts.

As an international agreement, it is not surprising that the IAC recognizes management rights of states, and seeks agreement among states to forgo some of those rights and to agree on management activities. For example, states agree to standardize management practices in a variety of ways, including eliminating withdrawal rights (Article IV), protecting turtle habitat (annex II), and using turtle excluder devices in shrimp trawls (annex III); see Campbell, Godfrey, and Drif (2002). However, the IAC's attempt to supersede the rights of sovereign states regarding withdrawal rights was not entirely successful. For example, any Party asking for an exception under Article IV, 3.a, after having considered the Consultative Committee's recommendations, is not bound by the recommendation. Attempts to make exceptions subject to unanimity among Parties failed.

Management rights in this instance can also be considered in terms of access to and influence on the IAC's decision-making process, and the IAC has an interesting history in this regard. The treaty is a result of intergovernmental negotiations that began in 1994. The original focus was on the use of turtle excluder devices (TEDs) in shrimp trawl nets, and the impetus was U.S. Public Law 101-162 that requires the use of TEDs by nations wishing to export shrimp to the United States (Frazier 2000). A hemispheric treaty on the use of TEDs was seen as an alternative to unilateral U.S. inspection and certification of foreign shrimp fleets and, in the early stages of negotiations, governments and fishing organizations dominated, with little participation by sea turtle experts. In contrast, in post-1995 negotiations, scientists, conservationists, and NGOs all played roles, and the IAC expanded beyond TEDs to include scientific research on sea turtles (Article VIII), habitat conservation and management (Article IV, 2.d., and annex II), and subsistence use of sea turtles (Article II, 3). Naro-Maciel (1998) and Frazier (2000) link this broadened scope to the inclusion of NGOs' concerns. States are the focus of decision making, however, scientists and NGOs also negotiated for seats on the Scientific and Consultative Committees respectively. For example, the director of ANAI's sea turtle project holds a seat on the Scientific Committee, and the CCC is one of three NGO representatives on the Consultative Committee. In contrast, local people have no formal means of accessing IAC decision making. Any assumptions about the role of NGOs in representing local people should be made with caution (Macdonald 1995; Meyer 1995; Howes 1997; Campbell, Godfrey, and Drif 2002), particularly in this case where the represented NGOs are Defenders of Wildlife (Mexico), World Wildlife Fund, and the CCC. ${ }^{15}$

As an international treaty, the IAC sees states as holding exclusion rights and seeks agreement among parties to exercise these to their fullest (i.e., eliminate withdrawal rights for everyone), in all but exceptional cases.

The Influence of Sea Turtle Status and Migrations on Rights in the IAC. The preamble to the IAC states that unspecified species of sea turtles in the Americas are considered "threatened or endangered, and that some of these species may face an imminent risk of extinction." Thus, global status as defined in the Red List is invoked as a justification for the treaty. This justification is interesting given that some of the regional turtle populations shared by signatory countries are currently believed to be increasing. Given that the treaty was tailored to the region, reference to the regional population status would have been justified.

The importance of sea turtle migrations as a motive for pursuing a regional treaty is also explicit. The preamble recognizes that: "sea turtles migrate widely throughout sea areas and that their protection and conservation require cooperation and coordination among States within the range of such species." Thus, all management decisions, including the decision to invoke 
an exception, need to account for impacts on regional sea turtle populations.

Because the IAC is a new convention and meetings to date have focused primarily on structural and administrative issues, the importance accorded to sea turtle status and migrations in the actual work of the convention has yet to be seen. However, leatherback status was discussed at the first meeting of the IAC's Scientific Committee, and a review was later posted on the IAC website (Chacón 2004). The review summarizes population trends separately for the Pacific and Atlantic, but a proposed resolution emerging from the Scientific Committee's meeting (and later adopted at the second Conference of the Parties, COP2CIT-001) applies to the conservation of leatherback sea turtles in general. The resolution's actions focus on the Pacific, but its preamble states that "some nesting colonies in the Wider Caribbean are decreasing" and makes no mention of regional increases.

\section{Interactions between Conservation at the Local, National, and International Levels}

The local, national, and international examples discussed above illustrate how property rights have been assigned for sea turtles at selected sites in Costa Rica and via an international agreement to which Costa Rica is signatory. But how do these examples, operating at different sociopolitical scales, interact?

Costa Rica has established itself as a leader in conservation in general (Evans 1999) and for sea turtles specifically. For example, the Secretariat for the IAC is housed in Costa Rica and the 2004 International Symposium on Sea Turtle Biology and Conservation was held in San José, the capital city. With seven members on the MTSG, Costa Rica's representation exceeds that of other Central American countries (with at most two members each). The CCC is one of the oldest sea turtle NGOs in the world and Tortuguero is one of the longest-studied nesting sites. In general, Costa Rica's approach to sea turtle conservation is a nonconsumptive one and, as discussed in the national examples, the rights of local people to use sea turtles as resources are superseded by the rights of tourists to visit them, of scientists to study them, and of conservationists to know they are protected (see also Campbell 2002a, 2002b). The Costa Rican government (responding to concerns of NGOs) has already eliminated the limited withdrawal rights for communities at Tortuguero, Limón, and Gandoca. The interests of the state and NGOs can be expected to coincide as long as ecotourism remains an important source of foreign exchange in the country. In this sce- nario, the Ostional egg harvest appears the "square peg" in the "round hole" of Costa Rican conservation. With its international and national commitments to exclusionary protection, what will Costa Rica do with the Ostional egg harvest?

Under the IAC, it is unlikely that the Ostional egg harvest would qualify as an exception. The harvest is neither for subsistence (the commercial sale of eggs generates an important source of cash income) nor is it undertaken by a traditional community (the community's establishment dates to the 1940s; Campbell 1998). Whether Costa Rica will invoke the exception clause for Ostional remains to be seen. The irony is that the closure of the egg harvest could threaten the nesting population-one of the biological justifications for the harvest being that removing a portion of eggs from the beach increases hatchling success. In contrast to Ostional, the arribada at Nancite Beach in Santa Rosa National Park is decreasing in size, and one factor that may contribute to this is the high level of sand contamination associated with rotting eggs, occurring when succeeding waves of nesting turtles unearth and rupture eggs laid by previous arribada nesters (Cornelius et al. 1991; Honarvar, Plotkin, and Spotila 2006). If this theory is correct, stopping the egg harvest could lead to similar declines in nesting. Furthermore, if the egg harvest has reduced the black market for turtle eggs from other beaches by flooding the market with plentiful and cheap legal eggs, closing the Ostional project could provide incentives for illegal harvest from other nesting beaches in Costa Rica.

Given experts' preference for nonconsumptive use via ecotourism, and the importance of ecotourism in Costa Rica, it is worth considering the role of ecotourism in Ostional. Based on research there during the mid-1990s, Campbell (1999) suggested that tourist displeasure with the egg harvest posed a potential threat to it. During the author's 2004 visit to Ostional, local tourism guides confirmed that tourists are often upset by the idea of egg harvesting, whether or not they witness it. The increase in tourism to Costa Rica in general may also influence sea turtle conservationists' views of the egg harvest in Ostional. When the Ostional project was initiated, it was widely discussed in the sea turtle community and most biologists supported it (Pritchard 1984). In 1995, Campbell (1997) found continued support among interviewed experts; although some experts were unwilling to state definitively that the harvest was biologically sustainable, they agreed that it appeared to be. Furthermore, very few experts saw tourism as a development strategy for Ostional; those who did suggested that it might help reduce dependence on the egg harvest rather 
than replace it, but were wary of its potential negative impacts on both the turtles and the community (Campbell 1997). Since then, ecotourism has become more widely promoted by sea turtle conservationists in general, and this enthusiasm may now extend to Ostional. During the 2004 International Symposium on Sea Turtle Biology and Conservation, four turtle biologists and conservationists working in Costa Rica suggested to the author that the Ostional egg harvest should end because (a) it goes against general Costa Rican conservation philosophy; (b) its existence detracts from conservation efforts elsewhere in the country; and (c) further tourism will provide greater revenue to local people in Ostional. ${ }^{16}$

Because sea turtle status and migrations are not easily invoked as arguments against egg harvesting at Ostional, the policy priorities of sea turtle conservation experts are revealed. Few sea turtle experts challenge the biological basis of the harvest, and thus decisions about whether harvesting in Ostional should continue or not will likely be caught up in wider beliefs about rights to resources, and more generally about conservation, development, and consumptive versus nonconsumptive use. In the arguments against the egg harvest listed above, biology and ecology are absent. Instead, the withdrawal rights of Ostional residents are depicted as conflicting with the rights of conservationists to see their vision of Costa Rican conservation dominate, and with the rights of tourists to witness undisturbed, people-free nature. Conservationists may sincerely believe that ecotourism will generate more revenue than the egg harvest, but other issues (distribution of revenue, tourism-linked inflation, and economic leakage) need to be considered before claims of ecotourism's greater value can be made (Honey 1999; Scheyvens 1999; Mowforth and Munt 2003). Furthermore, economic benefits of the egg harvest are only one factor contributing to the community's support for it. Management rights are a critical component of socioeconomic stability (Campbell 1998), and how these would change should Ostional turn exclusively to ecotourism, and the unlikelihood that these would be retained locally, should be taken into account.

\section{Discussion and Conclusions}

Regardless of how the Ostional egg harvest fares in the future, the local, national, and international examples discussed above illustrate that both scale and space, separately and in combination, present challenges for sea turtle conservation and dominate in conservation discourse. The global distribution and migrations of turtles, issues of space, are invoked by sea turtle experts to override local rights of withdrawal, management, and exclusion, and to assign these rights at other sociopolitical scales. National or international conservation priorities (currently coincidental due to the importance of ecotourism to both the state and conservation NGOs), issues of sociopolitical scale, are invoked to the same effect. Because of the difficulties and uncertainties associated with managing sea turtles across space and scale, the default management position advocated opposes consumptive use, and this is articulated at the international level and translated through national governments to local communities. Thus, scale and space combine to privilege certain approaches to studying sea turtle ecology (e.g., using satellite telemetry or DNA analysis to better understand long-distance migrations), certain conservation strategies (e.g., no use, or nonconsumptive use through tourism), and certain actors in the decision-making process (e.g., NGOs, governments, and scientists, working collaboratively at a regional and preferably global level).

Sea turtles do migrate, and some populations of sea turtles face high levels of threat; a critical realist approach demands that these biological and ecological facts be acknowledged. However, these are not the only facts, and that ecology is political is illustrated through the sometimes selective use of ecological data by conservationists. In the examples discussed, particularly at the national level, differences in species numbers across space are ignored or questioned, in spite (or because) of evidence that some regional populations, including olive ridleys in Ostional, greens in Tortuguero and Limón, and leatherbacks in Gandoca, are faring better than global species listings suggest. Which facts conservationists choose to highlight and what they do with them are of critical concern to political ecologists, as selective use can mask other issues such as beliefs about rights to resources. It is only when ecological data cannot be used to support a particular position (e.g., one in favor of the closure of the Ostional egg harvest) that these beliefs come to the surface. However, in articulating these beliefs about rights, scale remains important; when experts argue that egg harvesting in Ostional should be halted because it "doesn't fit" with Costa Rica's national approach, they are arguing about sociopolitical scale and preferencing the national over the local. Brown and Purcell (2005) argue that treating scale as an object of inquiry is one way to avoid falling into the "local trap," where activities at the local scale are assumed to be inherently more likely to have desired social and ecological effects than activities at other scales. This article uses scale as an object of inquiry in order to situate a local project within a wider political struggle over the scale at 
which conservation takes place. Ecological arguments do not exist in isolation, but are tied to this wider struggle and used in its service.

An important consequence of privileging the national and international is the potential marginalization of local people in determining, managing, and participating in locally meaningful conservation. Marginalization reflects unequal power in conservation, and Bryant (1998) distinguishes between different forms of power, including power over how resources are used (material practice) and power over ideas (discourse). This article has shown how an epistemic community of sea turtle conservation experts participates in receiving narratives and constructing discourses (i.e., controlling ideas) about sea turtle conservation. Political ecologists have studied experts and their discursive practices, but such studies have been critiqued for overemphasizing what experts "say" without understanding whether or not there are associated consequences (Watts 2000). By examining the political ecology of sea turtle conservation at multiple scales, this article illustrates that sea turtle experts do have power over material practice. ANAI and the CCC have influenced material practice at their field sites (promoting the elimination of withdrawal rights, promoting and playing an active role in tourism), and nationally (campaigning to end the sea turtle fishery in Limón). That these organizations are now officially represented on the Scientific and Consultative Committees of the IAC means they may have further impacts on material practice in Costa Rica and in other signatory countries. For example, the CCC's scientific director (until 2006) has been one of the main proponents of replacing consumptive with nonconsumptive use (Troëng and Drews 2004) and made a presentation on the economic superiority of ecotourism to the IAC's Scientific Committee (IAC 2004, 7). Thus, sea turtle biologists and conservationists play multiple roles, moving between the local, national, and international scales. ${ }^{17}$

That sea turtle biologists operate at different sociopolitical scales further contributes to understanding scale as political. First, it helps move away from the ontologically given notion of scale critiqued by Brown and Purcell (2005). Sea turtle biologists are at once local, national, and international actors. Although they would never relinquish their roles in local conservation activities (nor deny their importance), they align with the state when their interests coincide, and actively participate in international policy formation. Second, Brown and Purcell suggest that it is most often marginalized communities that try to "jump scale" when existing scalar arrangements do not suit them. Biologists and conservationists are seldom if ever characterized as marginalized in the conservation literature, but rather are the powerful elite. Part of this power may be derived from the ease with which they can "jump scales" to suit particular needs as a matter of expediency, rather than because they are marginalized. It is also possible that current emphasis on scaling-up conservation reflects expert dissatisfaction with existing scalar arrangements, a point revisited in the final paragraph.

The application of common property theory in this article has contributed to the analysis of the political ecology of sea turtle conservation, but it has also illustrated how common property theory can benefit from political ecology. First, regarding the benefits for political ecology, common property theory stresses the need to distinguish between different types of property rights, but the analysis in this article illustrates that sea turtle experts rarely make such distinctions; rights are rights to use resources (rights of withdrawal). However, withdrawal rights in themselves are not always enough to garner support for conservation, and management rights may be just as important to local communities. Recognizing such distinctions may help improve all types of conservation undertakings, including ecotourism projects. Ecotourism is seldom categorized as consumptive use, but thinking about the rights to benefit from tourism, to manage its development, and to decide who participates and who is excluded could help conservationists in designing and implementing projects that increase local participation in and benefits from ecotourism, and encourage greater support for it. By engaging conservationists in a broad discussion of property rights, political ecologists (and other social scientists) may contribute to improved conservation practice.

Second, regarding the benefits to common property theory, the article has shown that rights to highly valued resources and species are not just assigned (and negotiated, and contested) locally, but at other sociopolitical scales as well. Experts saw the rights of tourists, of the Costa Rican government, of Costa Ricans in general, of scientists, and of NGOs as equally (and sometimes more) compelling than those of local people, and national and international policy instruments reinforce this multiscalar view of rights. It is in this scaling-up of rights assignment that political ecology contributes to common property theory. The latter has been critiqued for focusing too much on local institutions and rational choices made by individuals, and for failing to put these institutions and choices into a broader historical, political, and social context (McCay 2002). For example, Agrawal $(2003,251)$ argues that the common property 
literature has tended to "ignore how the local is created in conjunction with the external and constituted in relation to its context." Similarly, Steins and Edwards $(1999,543)$ suggest that common property theory "focuses on the internal dynamics of resource management; that is, the resource system is studied in isolation from the wider political economy in which it is embedded." Political ecology's interest in scale forces a common property analyst to "look up" from the local to the other sociopolitical scales that contribute to this wider context. Giordano (2003) begins this process by highlighting the importance of scale in understanding the potential for common property management; it can be taken further by integrating an analysis of the politics of scale.

This article has examined the political ecology of sea turtle conservation, but there are lessons to be learned for conservation in general. Several concepts popular in conservation biology-migratory corridors, ecoregions, seascapes-all work at large geographic and sociopolitical scales, and Zimmerer (2006) categorizes current emphasis on such scales as part of the globalization of conservation. There may be biological justifications for approaching conservation at these scales, but, as this article shows, biological arguments cannot be separated from nonbiological ones (e.g., regarding rights to resources) and they warrant close scrutiny. Scaling-up conservation to account for a migratory corridor, for example, may also serve to bypass communities and place responsibility for conservation firmly in the hands of NGOs, national governments, and international organizations, whether or not this is the explicit intention of these actors. In some cases, scaling-up may not be biologically necessary and may even undermine existing conservation projects that are successful, but at the "wrong" (local) scale (for examples of the unintended consequences of globalized conservation, see Zimmerer 2006).

The move to scale-up conservation coincides with the backlash against community-based conservation discussed in the introduction (and detailed in Wilshusen et al. 2002), which is associated with the ongoing debate between the "pro-parks" and "pro-people" camps in conservation. In light of this debate, attempts to scale-up conservation can be interpreted as a strategy by the proparks camp in a wider political struggle over who should dictate and control conservation, and to change the terms of the debate itself. In this view "scale and scalar configurations are not an independent variable that can cause outcomes, rather they are a strategy used by political groups to pursue a particular agenda" (Brown and Purcell 2005, 608; emphasis in the original). It is the role of political ecologists to interrogate the consequences of such strategies and agendas for both people and resources. However, given their interests in human and biophysical systems, political ecologists may also be well positioned to contribute to policy reform that improves conservation outcomes, and to help move debates about conservation policy beyond what Brockington, Igoe, and Schmidt-Soltau (2006) and Redford, Robinson, and Adams (2006) have described as an unproductive impasse that results in conservation beneficial to neither people nor resources.

\section{Acknowledgments}

Most of the research summarized in this article was funded by the Social Sciences and Humanities Research Council of Canada. Zoë Meletis provided comments on early drafts of the manuscript, and my thinking regarding the links between common property, political ecology, and issues of scale has been greatly enhanced through ongoing discussions with Noella Gray. Matthew Godfrey checked my turtle "facts" and formatted figures. The final article benefited substantially from the insights of three anonymous reviewers.

\section{Notes}

1. Due to the breadth of work drawn on in this article, limited information on study sites, methods, and results is provided in footnotes in specific sections. Readers are directed to related publications for further detail.

2. The public popularity of sea turtles is reflected in an Internetbased study by Ellis (2003), who found that the third most popular type of volunteer tourism opportunity (i.e., working expeditions for tourists who pay financially and in-kind to participate in research and conservation projects) is to work with sea turtles, behind the general categories of "marine mammals" and "terrestrial mammals." A recent special issue of the Maritime Studies journal (MAST 2005) examines sea turtles as flagship species.

3. At the time of writing, membership of the MTSG has been dissolved and a reappointment process is underway. Prior to this, there were 293 members. Approximately 60 percent of these were from developed countries, and 35 percent were from the United States.

4. The success or failure of the national parks model is open to interpretation and depends on criteria adopted by the assessors. "Failure" here refers not to the absolute number of parks and protected areas in developing countries, which has increased dramatically over the past three decades (Zimmerer 2006), but to the failure of the exclusionary national parks approach to recognize wider socioeconomic realities, and to the conflicts between parks and people that have resulted. Traditional conservation activities have often proved inappropriate in developing countries where subsistence rural livelihoods are at stake, where limited funds are available for state-financed exclusionary protection, and where perceptions of nature as "sacred" and "separate" do 
not necessarily hold true with the local human population. The results can have negative impacts on biological conservation, but also raise concerns about the justice of a protected-areas approach.

5. In total, forty-two experts from Canada, the United States, and Costa Rica were interviewed in 1995 and 1996. Interviews were semistructured and guided by broad questions related to changing conservation policy and the emergence of sustainable use and community-based conservation as popularly promoted conservation tools. More specific questions about Costa Rican case study sites were included, although the amount of time spent on these varied greatly according to the experience of the interviewee. Interviews were conducted in the interviewee's home or office and lasted anywhere from fifty minutes to over two hours. Interviews were taped and transcribed verbatim, and have been analyzed from a variety of perspectives (Campbell 2000, $2002 \mathrm{a}, 2002 \mathrm{c}$ ). Although the interviews are now ten years old, the author is in regular contact with many of the interviewees and is involved in debates about sea turtle conservation policy. Instances where expert views have evolved or changed significantly are noted in the text, but overall the original analysis of expert views holds true today.

6. For the purposes of this article, tourists viewing sea turtles on nesting beaches are considered as exercising withdrawal rights. They are not physically obtaining a resource unit (at least not in the short term), but they are "withdrawing" an experience, one based on the presence of sea turtles. Their desires to do so often conflict directly with those of local people to access more traditional withdrawal rights.

7. The summary of the Ostional example is based on research conducted by the author in Ostional during 1994 and 1995, and on follow-up research conducted in 2004 and 2005. Research included in-depth interviews with key informants and 10 percent of the adult population, a household survey (conducted in both 1995 and 2004), and participant observation during eight months of residency in Ostional. Full results and analysis of the early field work can be found in Campbell (1998, 1999).

8. The summary of Costa Rica's approach to wildlife conservation is based on fieldwork undertaken in Costa Rica and at the specific field sites beginning in 1995, and on additional field work undertaken by the author and her graduate students since. Research methods have included interviews (and to a more limited extent surveys) with local residents, tourists, and employees of NGOs and government agencies working in the area, analysis of related management documents, and participant observation during field work (with individual seasons lasting anywhere from two weeks to four months). Methods and results associated with specific studies are detailed in Campbell (2002a, 2002b), Peskin (2002), Smith (2002), Gray (2003), and Campbell and Smith $(2005,2006)$.

9. The summarized analysis of the IAC is based on a more detailed analysis that used contemporary concepts in wildlife conservation to assess the extent to which the IAC accounted for these when it was originally crafted (see Campbell, Godfrey, and Drif 2002). In addition, the author participated in a preparatory meeting prior the first Convention of the Parties (COP), and has followed progress through reports emerging from subsequent COPs (all documents available at http://www.iacseaturtle.org/iacseaturtle/ English/home.asp).
10. Although the Cornelius et al. (1991) study is now dated, and the ability to assess the impact of harvesting regimes on sea turtles is compromised by their delayed sexual maturity (Mortimer 1995), the legal egg harvest has now been going on for close to twenty years. This is longer than estimates of ridley maturation times (eleven to nineteen years; see Chaloupka and Zug 1997; Zug, Kalb, and Luzar 1997) and this is possibly the most convincing argument vis-à-vis the sustainability of the harvest.

11. While living in Ostional, the author recovered a satellite transmitter that had been attached by biologist Heather Kalb to a turtle nesting on Nancite Beach. Schulz (1971) also found movement of olive ridleys between beaches on either side of the border between French Guiana and Suriname.

12. Costa Rica passed a law for the protection, conservation, and recovery of sea turtle populations in October 2000 (Law no. 8325). The law addresses various issues, including incidental capture of sea turtles in fisheries, regulation of turtle tourism, and punishments for illegal use of sea turtles. The collection of eggs by the Ostional EHP remains exempt from the latter under Article 6 of the new law.

13. Using the critically endangered status of the leatherback as a rationale, one Costa Rican biologist recently suggested to the author that the egg harvest in Ostional should be stopped because people cannot distinguish between the highly endangered leatherback and the legal olive ridley eggs supplied by Ostional (even though leatherback eggs can be identified by their larger size).

14. The full text of the convention can be found at http:// www.iacseaturtle.org/iacseaturtle/English/texto.asp.

15. Delegates are listed at: http://www.iacseaturtle.org/iacsea turtle/English/download/DelegadosdelComiteConsultivo.pdf.

16. These comments were made during the course of normal conversation, rather than via formal research. One of the four biologists who made these comments in 2004 was interviewed in 1995, and at that time supported the continuation of the egg harvest. All of them are associated with study sites in Costa Rica, and thus their views on conservation and development in general have been formally captured in related research.

17. Troëng's work also shows that sea turtle biologists move outside their areas of expertise. Troëng and Drews' (2004) arguments are based on an economic analysis of gross revenue generated by ecotourism versus consumptive use at a variety of case study sites. It has been criticized for use of gross revenues, failure to estimate the value of subsistence use, and inadequate statistical analysis (Moyle 2004).

\section{References}

Adams, W. M. 2001. Green development: Environment and sustainability in the Third World, 2nd ed. London: Routledge.

Adams, W. M., and D. Hulme. 2001. Conservation and community: Changing narratives, policies and practices in African conservation. In African wildlife and livelihoods: The promise and performance of community conservation, ed. D. Hulme and M. Murphree, 9-23. Oxford, U.K.: James Currey. 
Agrawal, A. 2003. Sustainable governance of common-pool resources: Context, methods, and politics. Annual Review of Anthropology 32:243-62.

Agrawal, A., and E. Ostrom. 2001. Collective action, property rights, and decentralization in resource use in India and Nepal. Politics and Society 29 (4): 485-514.

ANAI. 1995. Conservation of the leatherback turtle in Gandocal Manzanillo National Wildlife Refuge: Volunteers manual. San José, Costa Rica: ANAI.

Avens, L., J. Braun-McNeill, S. Epperly, and K. J. Lohmann. 2003. Site fidelity and homing behavior in juvenile loggerhead sea turtles (Caretta caretta). Marine Biology 143:21120.

Ballestero, J., R. M. Arauz, and R. Rojas. 2000. Management, conservation, and sustained use of olive ridley sea turtle eggs (Lepidochelys olivacea) in the Ostional Wildlife Refuge, Costa Rica: An 11 year review. In Proceedings of the 18th Annual Symposium on Sea Turtle Biology and Conservation, compiled by F. A. Abreu-Grobois, R. Briseño-Dueñas, R. Márquez-Millán, and L. Sarti-Martínez, 4-5. U.S. Department of Commerce, NOAA Tech. Memo. NMFS-SEFSC436.

Barrow, E., and M. Murphree. 2001. Community conservation: From concept to practice. In African wildlife and livelihoods: The promise and performance of community conservation, ed. D. Hulme and M. Murphree, 24-37. Oxford, U.K.: James Currey.

Bjorndal, K. A., and A. B. Bolten. 2003. From ghosts to key species: Restoring sea turtle populations to fulfill their ecological roles. Marine Turtle Newsletter 100:16-21.

Blaikie, P. 1999. A review of political ecology: Issues, epistemology, and analytical narratives. Zeitschrift für Wirtschaftsgeographie 43 (3-4): 131-47.

Bolten, A. B. 2003. Active swimmers-passive drifters: The oceanic stage of loggerheads in the Atlantic system. In Loggerhead sea turtles, ed. A. B. Bolten and B. E. Witherington, 63-78. Washington, DC: Smithsonian.

Bolten, A. B., and K. A. Bjorndal, eds. 1993. Marine turtles: An action plan for their conservation. Part I: 1993-1998. Washington, DC: IUCN/SSC Marine Turtle Specialist Group.

Bolten, A. B., K. A. Bjorndal, H. R. Martins, T. Dellinger, M. J. Biscoito, S. E. Encalada, and B. W. Bowen. 1998. Transatlantic developmental migrations of loggerhead sea turtles demonstrated by mtDNA sequence analysis. Ecological Applications 8:1-7.

Boulon, R., P. Dutton, and D. McDonald. 1996. Leatherback turtles (Dermochelys coriacea) on St. Croix, U.S. Virgin Islands: Fifteen years of conservation. Chelonian Conservation and Biology 2:141-47.

Bowen, B. W., and S. A. Karl. 1996. Population genetics, phylogeography, and molecular evolution. In The biology of sea turtles, ed. P. L. Lutz and J. A. Musick, 29-50. Boca Raton, FL: CRC Press.

Brechin, S. R., P. R. Wilshusen, C. L. Fortwangler, and P. C. West. 2002. Beyond the square wheel: Toward a more comprehensive understanding of biodiversity conservation as social and political process. Society $\mathbb{E}$ Natural Resources $15: 41-64$.

Brockington, D., J. Igoe, and K. Schmidt-Soltau. 2006. Conservation, human rights, and poverty reduction. Conservation Biology 20 (1): 250-52.

Brown, J. C., and M. Purcell. 2005. There's nothing inherent about scale: Political ecology, the local trap, and the politics of development in the Brazilian Amazon. Geoforum 36:607-24.

Bryant, R. L. 1998. Power, knowledge and political ecology in the third world: A review. Progress in Physical Geography 22 (1): 79-94.

Campbell, C. L., and C. J. Lagueux. 2005. Survival probability estimates for large juvenile and adult green turtles (Chelonia mydas) exposed to an artisanal marine turtle fishery in the western Caribbean. Herpetologica 61:91-103.

Campbell, L. M. 1997. International conservation and local development: The sustainable use of marine turtles in Costa Rica. PhD diss., Department of Geography, University of Cambridge, Cambridge, U.K.

. 1998. Use them or lose them? The consumptive use of marine turtle eggs at Ostional, Costa Rica. Environmental Conservation 24:305-19.

- 1999. Ecotourism in rural developing communities. Annals of Tourism Research 26 (3): 534-53.

- 2000. Human need in rural developing areas: Perceptions of wildlife conservation experts. The Canadian Geographer 44 (2): 167-81.

. 2002a. Conservation narratives and the "received wisdom" of ecotourism: Case studies from Costa Rica. International Journal of Sustainable Development 5 (3): 300-25.

. 2002b. Conservation narratives in Costa Rica: Conflict and co-existence. Development and Change 33 (1): 29-56.

- 2002c. Science and sustainable use: Views of conservation experts. Ecological Applications 12 (4): 1229-46.

Campbell, L. M., M. H. Godfrey, and O. Drif. 2002. Community based conservation via global legislation? Limitations of the Inter-American Convention for the Protection and Conservation of Sea Turtles. Journal of International Wildlife Law and Policy 5:121-43.

Campbell, L. M., and C. Smith. 2005. Volunteering for sea turtles? Characteristics and motives of volunteers working with the Caribbean Conservation Corporation in Tortuguero, Costa Rica. Special issue. MAST 3(2) and 4 (1): 169-94.

. 2006. What makes them pay? Understanding values of conservation volunteers in Tortuguero, Costa Rica. Environmental Management 38 (1): 84-98.

Campbell, L. M., and A. Vainio-Mattila. 2003. Participatory development and community-based conservation: Opportunities missed for lessons learned? Human Ecology 31 (3): 417-37.

Caribbean Conservation Corporation (CCC). 2003a. CCC playing major role in protecting Caribbean leatherbacks. Velador 1:4-5. Available at http://www.cccturtle.org/pdf/ velador/Velador-Issue1 2003.pdf (last accessed 3 May 2004).

. 2003b. General behavior patterns of sea turtles. Available at http://www.cccturtle.org/behav.htm\#mig (last accessed 24 July 2006).

Carr, A. 1981. Notes on the behavioral ecology of sea turtles. In Biology and conservation of sea turtles: Proceedings of World Conference on Sea Turtle Conservation, ed. K. Bjorndal, 1926. Washington, DC: Smithsonian Institute.

Chacón, D. 2004. Synopsis of the leatherback sea turtle (Dermochelys coriacea), INF-16-04: San José, Costa Rica: InterAmerican Convention for the Protection and Conservation of Sea Turtles. Available at http://www.iacseaturtle.org/ iacseaturtle/English/download/INF-16-04\%20eng.pdf (last accessed 15 May 2006). 
Chacón, D., and J. M. Hancock. 2004. Anidación de la tortuga Baula (Dermochelys coriacea) en Playa Gandoca, Talamanca, Costa Rica: Programa de conservación de tortugas marinas del Caribe Sur, Talamanca, Costa Rica [Nesting of leatherback turtles (Dermochelys coriacea) on Gandoca Beach, Talamanca, Costa Rica: Conservation program for marine turtles on the Caribbean Coast, Talamanca, Costa Rica], 77. San José, Costa Rica: ANAI.

Chaloupka, M., D. Parker, and G. Balazs. 2004. Modelling postrelease mortality of loggerhead sea turtles exposed to the Hawaii-based pelagic longline fishery. Marine EcologyProgress Series 280:285-93.

Chaloupka, M., and G. R. Zug. 1997. A polyphasic growthfunction for the endangered Kemp's ridley sea-turtle, Lepidochelys kempii. Fishery Bulletin 95:849-56.

Chaverri, D. C. 1999. Anidación de la tortuga Dermochelys coriacea en Playa Gandoca, Costa Rica (1990-1997) [Nesting of Dermochelys coriacea on Gandoca Beach, Costa Rica (1990-1997)]. Revista Biologica Tropical 47: 225-36.

Chaves, G. 2002. Plan de aprovechamiento para la utilización racional, manejo y conservacion de los huevos de la tortuga marina lora, Lepidochelys olivacea, en el Refugio de Vida Silvestre de Ostional, Santa Cruz, Guanacaste, Costa Rica [Approval plan of the rational use, management, and conservation of olive ridley turtle (Lepidochelys olivacea) eggs, in the Ostional Wildlife Refuge, Santa Cruz, Guanacaste, Costa Rica], 17. San José: School of Biology, University of Costa Rica.

Cornelius, S. E., M. A. Alvarado Ulloa, J. C. Castro, M. Malta de Valle, and D. C. Robinson. 1991. Management of olive ridley sea turtles (Lepidochelys olivacea) nesting at Playas Nancite and Ostional, Costa Rica. In Neotropical wildlife use and conservation, ed. J. G. Robinson and K. H. Redford, 111-35. Chicago: University of Chicago Press.

Cuevas, O. 2002. Tourism development alternative for the turtle fisher community of Limón, Costa Rica: Feasibility study and master plan. Consultants' report. San José, Costa Rica. Available at http://www.cccturtle.org/pdf/PROYECTO english.pdf (last accessed 5 February 2007).

Dutton, D. L., P. H. Dutton, M. Chaloupka, and R. H. Boulon. 2005. Increase of a Caribbean leatherback turtle Dermochelys coriacea nesting population linked to long-term nest protection. Biological Conservation 126 (2): 186-94.

Eckert, K. L., K. A. Bjorndal, F. A. Abreu-Grobois, and M. Donnelly, eds. 1999. Research and management techniques for the conservation of sea turtles. Publication no. 4. Washington, DC: IUCN/SSC Marine Turtle Specialist Group.

Eckert, K. L., S. A. Eckert, T. W. Adams, and A. D. Tucker. 1989. Inter-nesting migrations by leatherback sea turtles (Dermochelys coricea) in the West Indies. Herpetologica 45:190-94.

Ellis, C. 2003. Participatory environmental research in tourism: A global view. Tourism Recreation Research 28 (3): 45-55.

Evans, S. 1999. The green republic: A conservation history of Costa Rica. Austin: University of Texas Press.

Ferraroli, S., J. Y. Georges, P. Gaspar, and Y. Le Maho. 2004. Where leatherbacks meet fisheries. Nature 429:521-22.

Forsyth, T. 2003. Critical political ecology: The politics of environmental science. London: Routledge.

Frazier, J. 1999. Community-based conservation. In Research and management techniques for the conservation of sea turtles, ed. K. L. Eckert, K. A. Bjorndal, F. A. Abreu-Grobois, and M.
Donnelly, 15-18. Washington, DC: IUCN/SSC Marine Turtle Specialist Group.

- 2000. Building support for regional sea turtle conservation in ASEAN and the Asian region: Learning from the Inter-American Convention for the Protection and Conservation of Sea Turtles. In Sea turtles of the Indo-Pacific, ed. N. Pilcher and G. Ismail, 277-303. Sarawak, Malaysia: Institute of Biodiversity \& Environmental Conservation, University of Malaysia.

Freese, C. H. 1997. Harvesting wild species: Implications for biodiversity conservation. Baltimore: Johns Hopkins University Press.

- 1998. Wild species as commodities: Managing markets and ecosystems for sustainability. Washington, DC: Island Press.

Gerrodette, T., and B. L. Taylor. 1999. Estimating population size. In Research and management techniques for the conservation of sea turtles, ed. K. L. Eckert, K. A. Bjorndal, F. A. Abreu-Grobois, and M. Donnelly, 67-71. Washington, DC: IUCN/SSC Marine Turtle Specialist Group.

Giordano, M. 2003. The geography of the commons: The role of scale and space. Annals of the Association of American Geographers 93 (2): 365-75.

Girondot, M., and J. Fretey. 1996. Leatherback turtles, Dermochelys coriacea, nesting in French Guiana, 1978-1995. Chelonian Conservation and Biology 2:204-08.

Godfrey, M. H., and O. D. Drif. 2001. Guest editorial: Developing sea turtle ecotourism in French Guiana: Perils and practicalities. Marine Turtle Newsletter 91:1-4.

Gray, N. 2003. Global discourses, local views: Visions of volunteer ecotourism in Gandoca, Costa Rica. Master's thesis, Department of Geography, University of Western Ontario.

Gulko, D., and K. Eckert. 2004. Sea turtles: An ecological guide. Hawaii: Mutual Publishing.

Hackel, J. D. 1999. Community conservation and the future of Africa's wildlife. Conservation Biology 13 (4): 726-34.

Harrison, E., S. Troëng, M. Abrego, M. Becker, R. Beker, G. Castillo, and J. Fuentas de la Viuda et al. 2005. Report on the 2004 green turtle program at Tortuguero, Costa Rica. San José, Costa Rica: Caribbean Conservation Corporation.

Hasting, M. 2003. A conservation success: Leatherback turtles in the British Virgin Islands. Marine Turtle Newsletter 99:57.

Heinen, J. T. 1993. Park-people relations in Kosi Tappu Wildlife Reserve, Nepal: A socio-economic analysis. Environmental Conservation 20 (1): 25-33.

Honarvar, S., P. Plotkin, and J. R. Spotila. 2006. Where have all the ridleys gone? The decline of the arribada at Playa Nancite Costa Rica. Paper presented at the 26th Annual Symposium on Sea Turtle Biology and Conservation, 3-8 April, Crete.

Honey, M. 1999. Ecotourism and sustainable development: Who owns paradise? Washington, DC: Island Press.

Howes, M. 1997. NGOs and the institutional development of membership organisation: A Kenyan case study. Journal of Development Studies 33 (6): 820-47.

Hughes, G. R., P. Luschi, R. Menacci, and F. Papi. 1998. The $7000-\mathrm{km}$ oceanic journey of a leatherback turtle tracked by satellite. Journal of Experimental Marine Biology and Ecology 229:209-17.

Hulme, D., and M. Murphree, eds. 2001. African wildlife and livelihoods: The promise and performance of community conservation. Oxford, U.K.: James Currey. 
IAC. 2004. Minutes of first meeting of the scientific committee. Inter-American Convention for the Protection and Conservation of Sea Turtles. Available on-line at: http://www. iacseaturtle.org/iacseaturtle/English/download/Minutes\%20I\% 20Meeting\%20Scientific\%20Committee.pdf (last accessed 16 May 2006).

- 2005. Minutes of second meeting of the scientific committee. Inter-American Convention for the Protection and Conservation of Sea Turtles. Available on-line at: http://www.iacseaturtle.org/iacseaturtle/English/download/ Minuta\%202\%AAScC\%20final\%20ENG.pdf (last accessed 16 May 2006).

IUCN (the World Conservation Union). 1980. The world conservation strategy. Gland, Switzerland: IUCN.

Jacobson, S. K., and R. Robles. 1992. Ecotourism, sustainable development, and conservation education: Development of a tour guide training program in Tortuguero, Costa Rica. Environmental Management 16 (6): 701-13.

James, M. C., C. A. Ottensmeyer, and R. A. Myers. 2005. Identification of high-use habitat and threats to leatherback sea turtles in northern waters: New directions for conservation. Ecology Letters 8:195-201.

Lee, D. N. B., and D. J. Snepenger. 1992. An ecotourism assessment of Tortuguero, Costa Rica. Annals of Tourism Research 19 (2): 367-70.

Lefever, H. G. 1992. Turtle bogue: Afro-Caribbean life and culture in a Costa Rican village. Cranbury, NJ: Associated University Press.

Lundy, P. 1999. Community participation in Jamaican conservation projects. Community Development Journal 34 (2): 122-32.

Luschi, P., G. C. Hays, C. Del Seppia, R. Marsh, and F. Papi. 1998. The navigational feats of green sea turtles migrating from Ascension Island investigated by satellite telemetry. Proceedings of the Royal Society of London B 265:2279-84.

Lutcavage, M. E., P. Plotkin, B. Witherington, and P. Lutz. 1997. Human impacts on sea turtle survival. In The biology of sea turtles, ed. P. L. Lutz and J. A. Musick, 387-409. Boca Raton, FL: CRC Press.

Macdonald, L. 1995. NGOs and the problematic discourse of participation: Cases from Costa Rica. In Debating development discourse: Institutional and popular perspectives, ed. D. B. Moore and G. J. Schmitz, 201-29. New York: St. Martin's Press.

Márquez, M. R., C. Peñaflores, and J. C. Vasconcelos. 1996. Olive ridley turtles (Lepidochelys olivacea) show signs of recovery at La Escobilla, Oaxaca. Marine Turtle Newsletter 73:5-7.

MAST. 2005. Special issue: Marine turtles as flagship. MAST 3 (2) and 4 (1)

McCay, B. 2002. Emergence of institutions for the commons: Contexts, situations, and events. In The drama of the commons, ed. E. Ostrom, T. Dietz, N. Dolšak, P. C. Stern, S. Stonich, and E. U. Weber, 361-402. Washington, DC: National Academy Press.

McCormick, J. 1989. The global environmental movement: Reclaiming paradise. London: Belhaven.

Meyer, C. A. 1995. Northern donors for Southern NGOs: Consequences in local participation and production. Journal of Economic Development 20 (2): 7-22.

Mortimer, J. A. 1995. Teaching critical concepts for the conservation of sea turtles. Marine Turtle Newsletter 71:1-4.
Mowforth, M., and I. Munt. 2003. Tourism and sustainability: Development and new tourism in the Third World, 2nd ed. London: Routledge.

Moyle, B. 2004. Book Review of Money talks: Economic aspects of marine turtle use (by Troëng and Drews, 2004). Sustainable, September 2004. Available online at: http://www.iucn.org/ themes/ssc/susg/SustainableSept04/WWF Turtles.htm (last accessed 15 May 2006).

Mrosovsky, N. 1997. IUCN's credibility threatened. Nature 389:436.

- 2003. Predicting extinction: Fundamental flaws in IUCN's Red List system, exemplified by the case of sea turtles. Toronto: University of Toronto Press. Available at http://members. seaturtle.org/mrosovsky/ (last accessed at 16 May 2006).

. 2004. Conceptual problems with the IUCN Red Listing assessment for the green turtle: Move over Raine Island. Marine Turtle Newsletter 106:1-3.

MTSG. 1995. A global strategy for the conservation of marine turtles. Gland, Switzerland: IUCN.

Naro-Maciel, E. 1998. The Inter-American Convention for the Protection and Conservation of Sea Turtles: An historical overview. International Journal of Wildlife Law and Policy 1 (1): 169-78.

Neumann, R. P. 1998. Imposing wilderness: Struggles over livelihood and nature preservation in Africa. Berkeley: University of California Press.

Oates, J. F. 1999. Myth and reality in the rain forest: How conservation strategies are failing in West Africa. Berkeley: University of California Press.

Parry, D., and B. Campbell. 1992. Attitudes of rural communities to animal wildlife and its utilization in Chobe Enclave and Mababe Depression, Botswana. Environmental Conservation 19 (3): 245-51.

Parsons, J. 1962. The green turtle and man. Gainesville: University of Florida Press.

Peskin, J. D. 2002. Local guides' attitudes toward ecotourism, sea turtle conservation, and guiding in Tortuguero, Costa Rica. MSc thesis, Department of Geography, University of Florida, Gainesville.

Plotkin, P. T., R. A. Byles, D. C. Rostal, and D. W. Owens. 1995. Independent versus socially facilitated oceanic migrations of the olive ridley, Lepidochelys olivacea. Marine Biology 122:137-43.

Pretty, J. N. 1995. Participatory learning for sustainable agriculture. World Development 23 (8): 1247-63.

Pritchard, P. 1984. Guest editorial: Ostional management options. Marine Turtle Newsletter 31:2-4.

- 1997a. Evolution, phylogeny, and current status. In The biology of sea turtles, ed. P. L. Lutz and J. A. Musick, 128. Boca Raton, FL: CRC Press.

. 1997b. A new interpretation of Mexican ridley population trends. Marine Turtle Newsletter 76:14-17.

Redford, K. H., J. G. Robinson, and W. M. Adams. 2006. Parks as shibboleths. Conservation Biology 20 (1): 1-2.

Roe, E. 1991. Development narratives, or making the best of blueprint development. World Development 19 (4): 287300.

Salmon, M., and J. Wyneken. 1994. Orientation in hatchling sea turtles: Mechanisms and implications. Herpetological Natural History 2:13-24.

Scheyvens, R. 1999. Ecotourism and the empowerment of local communities. Tourism Management 20:245-49. 
Schulz, J. P. 1971. Nesting beaches of sea turtles in west French Guiana. Koninkl. Nederl. Akademie van WetenschappenAmsterdam 74 (4): 396-404.

Seminoff, J. A. 2004a. Global status assessment for the green turtle (Chelonia mydas), 34. Washington, DC: IUCN/ Marine Turtle Specialist Group. Available on-line at: http:// www.iucn-mtsg.org/red list/cm/MTSG Chelonia mydas Assessment April-2004.pdf (last accessed 25 July 2006).

- 2004b. Sea turtles, Red Listing, and the need for regional assessments. Marine Turtle Newsletter 106:4-6.

Smith, C. 2002. Valuing and volunteering for wildlife conservation in Tortuguero, Costa Rica. Master's thesis, Department of Geography, University of Western Ontario, London, ON.

Spotila, J. R., R. D. Reina, A. C. Steyermark, P. T. Plotkin, and F. V. Paladino. 2000. Pacific leatherback turtles face extinction. Nature 405 (6786): 529-30.

Steins, N. A., and V. M. Edwards. 1999. Collective action in common-pool resource management: The contribution of a social constructivist perspective to existing theory. Society and Natural Resources 12:539-57.

Stewart, K., and C. Johnson. 2006. The turtles of Florida: Dermochelys coriacea-Leatherback sea turtle. In Biology and conservation of Florida turtles, Chelonian Research Monographs, no. 3, ed. P. A. Meylan, 144-57. Lunenburg, MA: Chelonian Research Foundation.

Stonich, S. C. 1998. Political ecology of tourism. Annals of Tourism Research 25 (1): 25-54.

Taft, C. 1999. Lawsuit bans sea turtle killing in Costa Rica. Velador, Spring, 2.

Terborgh, J. 1999. Requiem for nature. Washington, DC: Island Press.

. 2000. The fate of tropical forests: A matter of stewardship. Conservation Biology 14 (5): 1358-61.

Tremblay, P. 2001. Wildlife tourism consumption: Consumptive or non-consumptive. International Journal of Tourism Research 3:81-86.

Troëng, S., C. Castro, and E. Chamorro. 2004. Economic consequences of the green turtle ban in Costa Rica. In Proceedings of the 24th Annual Symposium on Sea Turtle Biology and Conservation, San José, Costa Rica, 23-27 February. NOAA technical memorandum.
Troëng, S., D. Chacón, and B. Dick. 2004. Possible decline in leatherback turtle Dermochelys coriacea nesting along the coast of Caribbean Central America. Oryx 38:395-403.

Troëng, S., and C. Drews. 2004. Money talks: Economic aspects of marine turtle use and conservation. Gland, Switzerland: WWF-International.

Troëng, S., and E. Rankin. 2005. Long-term conservation efforts contribute to positive green turtle (Chelonia mydas) nesting trend at Tortuguero, Costa Rica. Biological Conservation 121:111-16.

Walker, P. A. 2005. Political ecology: Where is the ecology? Progress in Human Geography 29 (1): 73-83.

Watts, M. 2000. Political ecology. In A companion to economic geography, ed. E. Sheppard and T. Barnes, 257-74. Malden, MA: Blackwell.

Wells, M. P., and K. E. Brandon. 1993. The principles and practice of buffer zones and local participation in biodiversity conservation. Ambio 22 (2-3): 57-162.

Western, D., and M. A. Wright. 1994. Natural connections: Perspectives on community-based conservation. Washington, DC: Island Press.

Wilshusen, P. R., S. R. Brechin, C. L. Fortwangler, and P. C. West. 2002. Reinventing a square wheel: Critique of a resurgent "protection paradigm" in international biodiversity conservation. Society $\mathcal{E}$ Natural Resources 15 (1): $17-40$.

Young, E. 2001. State intervention and abuse of the commons: Fisheries development in Baja California Sur, Mexico. Annals of the Association of American Geographers 91 (2): 283-306.

Zimmerer, K. S. 2006. Cultural ecology: At the interface with political ecology: The new geographies of environmental conservation and globalization. Progress in Human Geography 30 (1): 63-78.

Zimmerer, K. S., and T. J. Bassett. 2003. Approaching political ecology: Society, nature, and scale in human-environment studies. In Political ecology: An integrative approach to geography and environment-development studies, ed. K. S. Zimmerer and T. J. Bassett, 1-28. New York: Guilford Press.

Zug, G. R., H. J. Kalb, and S. J. Luzar. 1997. Age and growth in wild Kemp's ridley sea turtles Lepidochelys kempii from skeletochronological data. Biological Conservation 80: 261-68.

Correspondence: Nicholas School of Environment and Earth Sciences, Duke University Marine Lab, 135 Marine Lab Road, Beaufort, NC, 28516, e-mail: lcampbe@duke.edu. 